Maurer School of Law: Indiana University

$4-15-2020$

\title{
The Grip of Nationalism on Corporate Law
}

Mariana Pargendler

marianapargendler@gmail.com

Follow this and additional works at: https://www.repository.law.indiana.edu/ilj

Part of the Agency Commons, Law and Economics Commons, Law and Politics Commons, and the Law and Society Commons

\section{Recommended Citation}

Pargendler, Mariana (2020) "The Grip of Nationalism on Corporate Law," Indiana Law Journal: Vol. 95 : Iss. 2 , Article 5.

Available at: https://www.repository.law.indiana.edu/ilj/vol95/iss2/5

This Article is brought to you for free and open access by the Law School Journals at Digital Repository @ Maurer Law. It has been accepted for inclusion in Indiana Law Journal by an authorized editor of Digital Repository @ Maurer Law. For more information, please contact rvaughan@indiana.edu.

\section{$\Psi$}

JEROME HALL LAW LIBRARY

INDIANa UNIVERSITY

Maurer School of Law
Bloomington 


\title{
The Grip of Nationalism on Corporate Law
}

\author{
MARIANA PARGENDLER*
}

INTRODUCTION

After decades of increased economic integration, nationalistic sentiment and protectionist policies are back in vogue, raising questions about the future of globalization. This tension is not new, but it matters. Countries have long adopted different and changing attitudes towards free trade or the protection of local industries, with significant economic and social repercussions. The current resurgence of nationalist impulses in the face of globalization may well be "the struggle of our time." 1

There is a long-running debate about the effects of globalization on corporate governance. Proponents of the convergence thesis have argued that, by increasing competition in product and capital markets, globalization would push countries to adopt efficient corporate governance practices that privilege the interests of outside investors, possibly leading to the "end of history for corporate law." ${ }^{2}$ Skeptics have at most warned that path dependence and interest group pressure will permit some persistence of traditional differences in corporate governance despite the powerful forces of globalization and efficiency. ${ }^{3}$ Both camps focus on the role of corporate law in reducing agency costs, but diverge about whether a single efficient model will

* Professor of Law, Fundação Getulio Vargas School of Law in São Paulo; Global Professor of Law, New York University School of Law; Research Member, European Corporate Governance Institute (ECGI). I am grateful to Ian Ayres, Sheila Cerezetti, Kevin Davis, Paul Davies, Luca Enriques, George Georgiev, Jeffrey Gordon, Zohar Goshen, Henry Hansmann, Klaus Hopt, Michael Klausner, Curtis Milhaupt, John Morley, Katharina Pistor, Claire Priest, Dan Puchniak, Hyeok-Joon Rho, Roberta Romano, Bruno Salama, David Schleicher, Leo Strine, and participants at the 2019 Annual Meeting of the American Law and Economic Association (ALEA) and faculty workshops at Columbia, FGV and Yale Law Schools for their very helpful comments and suggestions. I also gratefully acknowledge financial support from São Paulo Research Foundation (FAPESP) based on grant 2019/05340-0. All errors are my own.

1. Sarah Frier, Zuckerberg Asks Harvard Grads to Fight Isolationism, Nationalism, BloOMBERG (May 25, 2017, 4:43 PM), https:/www.bloomberg.com/news/articles/2017-0525/zuckerberg-asks-harvard-grads-to-fight-isolationism-nationalism [https://perma.cc/9PJJ7RHH]; Yuval Noah Harari \& Chris Anderson, Nationalism vs. Globalism: The New Political Divide, TED (Feb. 2017), https://www.ted.com/talks/yuval_noah_harari_nationalism_vs globalism_the_new_political_divide [https://perma.cc/9L8R-SHSP].

2. See, e.g., Jeffrey N. Gordon \& Mark J. Roe, Introduction, in CONVERGENCE AND Persistence in Corporate Governance 1-2 (Jeffrey N. Gordon \& Mark J. Roe eds., 2004); Henry Hansmann \& Reinier Kraakman, The End of History for Corporate Law, 89 GeO. L.J. 439 (2001); see also Raghuram G. Rajan \& Luigi Zingales, The Great Reversals: The Politics of Financial Development in the Twentieth Century, 69 J. FIN. ECON. 5 (2003) (providing an influential empirical study suggesting that incumbents will oppose financial development when the economy is closed but not when it is open to cross-border trade and capital flows).

3. See, e.g., Lucian Arye Bebchuk \& Mark J. Roe, A Theory of Path Dependence in Corporate Ownership and Governance, 52 STAN. L. REV. 127 (1999). 
emerge given the existing differences in ownership structures and in the power of distinct interest groups.

Yet, this prevailing debate has overlooked key elements in the structure of national politics and the role of corporate arrangements as an instrument and expression of economic nationalism. In this Article, I document and explain the pervasive influence of nationalist impulses in shaping corporate law around the world and throughout history - a phenomenon which I term "the grip of nationalism on corporate law." This effort shows that nationalist influence on corporate law is old, widespread, and resilient, and has put sand in the gears of globalization.

Nationalism - here understood as the political resolve to favor territorial insiders over outsiders through protectionist policies ${ }^{4}$ - has left an imprint on the most important features of the governance landscape, ranging from ownership structures and takeover defenses to choice of law and investor protection. The use of corporate law mechanisms to ensure domestic control of business corporations has been particularly salient. France and Germany first embraced multivoting and nonvoting stock in the early twentieth century to ward off foreign domination of local companies. A key motive behind state ownership of enterprise in most jurisdictions, from Norway to Brazil, is to ensure domestic control and headquarters of strategic industries. Fears of foreign acquisitions have profoundly shaped takeover legislation worldwide, to the point that numerous legal reforms bear the name of a conspicuous foreign bidder, such as the "Danone amendment" in France, the "Lactalis decree" in Italy, and the "Cadbury law" in the United Kingdom.

We do not usually think of U.S. corporate law as reflecting nationalist concerns, but analogous forces of state-level patriotism (or statism, rather than nationalism, if you will) have fundamentally shaped its course. U.S. firms have repeatedly obtained state antitakeover legislation in response to hostile threats by out-of-state bidders. Nationalist discourse against foreign ownership has also occasionally left a mark on U.S. federal legislation, from the charter provisions disenfranchising foreign investors in the First and Second Bank of the United States in the nineteenth century to the enactment of regulatory restrictions on hostile takeovers in the Williams Act of 1968.

4. For a similar loose use of nationalism as the rough equivalent of "economic nationalism," "protectionism," and "economic patriotism" for ease of recognition, see Helen Callaghan, Economic Nationalism, Network-Based Coordination, and the Market for Corporate Control: Motives for Political Resistance to Foreign Takeovers (Max-PlanckInstitut für Gesellschaftsforschung, Working Paper No. 12/10, 2012). Because this definition is sufficiently broad to encompass subnational or supranational political unities, a more accurate, though less used, term would be economic patriotism. See Ben Clift \& Cornelia Woll, Economic Patriotism: Reinventing Control over Open Markets, 19 J. EuR. PuB. PoL'Y 307, 308 (2012) ("Unlike economic nationalism, economic patriotism is agnostic about the precise nature of the unit claimed as patrie: it can also refer to supranational or sub-national economic citizenship."). However, unlike the conception of nationalism used in this Article, Clift and Woll's definition of economic patriotism is neutral as to its policy content, thus allowing for the pursuit of economic patriotism through liberal economic policies so long as they are meant to favor citizens over foreigners. Id. at 309, 313. 
Nationalist or integrationist objectives, rather than the agency cost considerations that dominate the literature, are the proximate cause of corporate reforms with surprising frequency. Although the influence of nationalism on corporate governance reforms is not a new theme (nor could it be, given how often it is invoked in public discourse), existing accounts of the phenomenon are rare. The few case studies of individual countries that do touch on this subject leave the false impression that the interaction between nationalism and corporate law is jurisdiction specific, ${ }^{5}$ or of modest importance. ${ }^{6}$ In fact, it is ubiquitous and consequential, and therefore worthy of systematic attention.

At least three factors promote the grip of nationalism on corporate law:

The political deficit of foreigners. Because only citizens vote, the political economy of corporate governance, as of everything else, is tilted against foreign interests. In the absence of international coordination, legal outcomes tend to favor domestic parties over foreign ones and local welfare over global welfare. In the corporate governance arena, lawmakers tend to privilege the interests of domestic managers, controlling shareholders, and workers over those of foreign investors. Although the political deficit of foreigners is well known in international law (and has led to the proliferation of bilateral investment treaties seeking to protect foreign investors from subsequent expropriation), the corporate governance literature has completely ignored it to date. Instead, it assumes that globalization will inexorably push countries to offer ever-greater protection to foreign investors.

The powerful alliance of domestic forces. The pursuit of nationalist policies through corporate law benefits from the powerful domestic alliance between elite and labor interests in retaining local corporate control and the popular appeal of nationalist sentiment. Corporate takeovers can be unpopular, but foreign takeovers are far more likely to trigger commotion and political action. To succeed, the pursuit of nationalism through corporate law need not be genuine or welfare enhancing; nationalism often can and does serve as a smokescreen for purely private interests. ${ }^{7}$ However, it is not easy to dismiss nationalist arguments as purely empty or opportunistic rhetoric. The existing evidence on the economic impact of foreign direct investment and foreign takeovers is mixed, adding a patina of legitimacy to nationalist corporate laws. ${ }^{8}$

The use of corporate law as stealth protectionism. Constitutional commitments to economic integration and international concerns over reciprocity favor the use of

5. The conflation of nationalism with individual countries' national histories - and, therefore, the neglect of nationalism as a systematic phenomenon-is also common among historians. John Breuilly, Introduction: Concepts, Approaches, Theories, in THE OxforD HANDBOOK OF THE History OF NATIONALiSM 1 (John Breuilly ed., 2013) ("Nationalism is treated by professional historians as one aspect of national history rather than a subject in its own right.").

6. To be sure, the role of nationalist impulses is a recurrent theme in E.U. corporate law - not least because its primary goal is precisely to overcome protectionist tendencies to promote economic integration. For a prominent collection of works examining the developments in the 2000s, see Company Law And Economic Protectionism: New Challenges to European InTEgration (Ulf Bernitz \& Wolf-Georg Ringe eds., 2010).

7. See infra note 308 and accompanying text.

8. See infra Part II. 
corporate law as a form of covert protectionism. Corporate law rules can be protectionist in effect without being discriminatory on their face. Overt legal discrimination against out-of-state interests can be unlawful from a domestic or supranational perspective or uncomfortable from an international relations perspective. Countries typically want to insulate national champions from foreign takeover threats, but also encourage their own business corporations to pursue targets abroad. Corporate law thus serves as an effective, but less obvious, form of protectionist intervention. Rules of corporate law and ownership structures serve multiple purposes and are often nondiscriminatory on their face but can work as a potent tool to shield local firms against foreign threats.

This Article does not seek to resolve the ongoing debate about the merits of nationalist policies, which may well be deleterious in some contexts and welfare enhancing in others. Instead, it seeks to underscore the grip of nationalism on corporate law and its significant implications for existing theories on the determinants of corporate governance. It draws attention to a critical factor missing from conventional accounts of the evolution of corporate law, raises the possibility of backlash in the future of corporate governance, and complicates the normative analysis of corporate institutions by pointing to a broader set of economic and geopolitical considerations.

The dominant debate about the determinants of corporate governance gravitates towards two different high-level explanations. Efficiency accounts posit that corporate law outcomes reflect basic economic exigencies, notably the reduction of agency costs among managers, shareholders, and creditors that plague the corporate form. ${ }^{9}$ Under this view, legal systems around the world tend to converge towards the optimal regime that best mitigates agency costs and increases firm value. ${ }^{10}$ Political accounts emphasize the role of interest groups in shaping corporate governance. ${ }^{11}$ This line of work typically stresses the role of history, ideology, and path dependence in forging the content of legal and economic institutions. These studies focus primarily on the special interests and power of managers, shareholders, and workers as the relevant constituencies.

The grip of nationalism on corporate law shows that these conventional accounts are unduly narrow. By focusing exclusively on agency costs, efficiency accounts have neglected the other possible ways in which corporate law can affect social welfare, such as by influencing economic integration, national security, and local development. At the same time, existing political accounts have overlooked the popular appeal of nationalist corporate policies and the interests of broader segments of the population on corporate governance outcomes. The grip of nationalism thus underlines how corporate governance arrangements matter in ways that transcend the

9. For an exposition of this perspective, see, e.g., John Armour, Henry Hansmann, Reinier Kraakman \& Mariana Pargendler, What Is Corporate Law?, in THE ANATOMY of CORPORATE LAW: A COMPARATIVE AND FunCTIONAL APPROACH 1 (2017).

10. Hansmann \& Kraakman, supra note 2, at 440.

11. For prominent political accounts, see, e.g., Peter Alexis Gourevitch \& James J. Shinn, Political Power and Corporate Control: The New Global Politics of Corporate Governance (2005); Mark J. Roe, Strong Managers, Weak Owners (1994); Marco Pagano \& Paolo F. Volpin, The Political Economy of Corporate Governance, 85 AM. ECON. REV. 1005 (2005). 
concerns about firm-level efficiency and firm-level politics that have dominated the field.

The strength of nationalist forces also suggests that the usual forecasts about the effects of globalization on corporate law may be flawed. The existing predictions have alternated exclusively between the prospect of convergence towards more efficient corporate laws that better protect outside investors ${ }^{12}$ or the possibility of persistence of traditional differences in corporate governance despite the powerful thrust of globalization. ${ }^{13}$ Yet, the combination of rising foreign ownership with the political deficit of foreigners can lead to a different, but unforeseen, scenario: neither convergence nor persistence, as conventionally assumed, ${ }^{14}$ but backlash. Once foreign investors come to dominate local capital markets, as is increasingly the case,${ }^{15}$ there may be greater political pressure towards investor-unfriendly corporate reforms - a trend that I suggest may well be under way.

The remainder of this Article proceeds as follows. Part I provides a brief overview of the relationship between corporate law and nationalism and demonstrates their interaction in the historical experiences of several key jurisdictions. These vignettes are merely illustrative, but they indicate how deep the link between nationalism and corporate law can be. Part II summarizes the evidence on the economic effects of foreign corporate control, showing that it is ultimately inconclusive. Part III explains why corporate law can be an attractive instrument to accomplish nationalist objectives and explores the possible regulatory responses to this phenomenon. Part IV analyzes the implications of these findings for future developments in corporate lawmaking. Part V concludes by reflecting on the prospect of the bond between nationalism and corporate law.

\section{NATIONALISM AND CORPORATE LAW: THE HistoriCAL AND COMPARATIVE EXPERIENCE}

The relationship between nationalism and corporate law is complex and multidirectional. Autarky and globalization can have an indirect effect on corporate laws and governance arrangements - with autarky discouraging, and globalization promoting, investor protection and financial development. ${ }^{16}$ Yet corporate governance change is not only a byproduct of free trade or protectionist policies. Corporate law itself can operate as a conduit for nationalism or economic integration by promoting or thwarting cross-border investment. Whereas the indirect effects of

12. See, e.g., Hansmann \& Kraakman, supra note 2; Merrit Fox, The Rise of Foreign Ownership and Corporate Governance, in OXFORD HANDBOOK OF CORPORATE LAW AND Governance 35 (Jeffrey N. Gordon \& Wolf-Georg Ringe eds., 2017).

13. See, e.g., Bebchuk \& Roe, supra note 3 , at 137.

14. For an influential collection of essays framed in these terms, see CONVERGENCE AND Persistence in Corporate Governance (Jeffrey N. Gordon \& Mark J. Roe eds., 2004); see also Jeffrey N. Gordon, Convergence and Persistence in Corporate Law and Governance, in OXFoRd HANDBOOK OF CORPORATE LAW AND GovernanCE (Jeffrey N. Gordon \& WolfGeorg Ringe eds., 2017) (arguing that there has been "divergence in convergence" in the last fifteen years).

15. See infra Table 1.

16. See supra note 2 and accompanying text. 
economic openness (or lack thereof) on corporate law are well known, the role of corporate law in shaping economic integration remains understudied. ${ }^{17}$

In fact, the impact of nationalist concerns on corporate law reform is surprising given how messy the relationship between corporations and nation-states can be. ${ }^{18}$ Corporations are legal entities, created by a state, that can have relationships with individuals, firms, and other states. The largest business corporations are usually multinationals, operating across jurisdictional boundaries. What, then, is the adequate hook for the attribution of nationality and the application of the state's laws, sovereign powers, and protection?

This question allows for different doctrinal answers. Some jurisdictions, notably the United Kingdom and the United States, have embraced the state of incorporation as the primary determinant of corporate nationality. Countries in Continental Europe, by contrast, had historically opted for the principal place of business (siège réel or "real seat") as the relevant criterion. ${ }^{19}$ Nevertheless, jurisdictions from both camps have sporadically abandoned such doctrinal purities (themselves shaped by nationalist considerations, or lack thereof ${ }^{20}$ ) to inquire into the nationality of control, especially with respect to strategic sectors and in times of war. ${ }^{21}$

The legal concept of corporate control first emerged to protect national security, not to mitigate agency costs. ${ }^{22}$ However, as corporate lawyers well know, it is difficult to create a universal test to identify corporate control in all instances. Unsurprisingly, relevant statutes and judicial decisions have used different threshold requirements for national shareholdings and board membership, depending on the historical context and industry in question. The central idea motivating the inquiry into corporate control is that the nationality of the individuals who control the firm determines their loyalty to the nation.

Nationalist influence on corporate governance can take different forms. First and most importantly, control nationalism seeks to preserve domestic control of major business corporations. At a basic level, domestic control can be a symbol of national power and pride that epitomizes nationalism irrespective of its effects on the economic well-being of citizens. Citizens may prefer domestic control for the same reason that they cheer for their national sports team.

17. For a notable exception, see Jeffrey N. Gordon, The International Relations Wedge in the Corporate Convergence Debate, in CONVERGence AND PERSISTENCE IN Corporate GOVERNANCE, supra note 14 (arguing that economic integration is best served by the diffusion of Anglo-Saxon model of widely held firms whose control is contestable).

18. See, e.g., Mihir A. Desai, The Decentering of the Global Firm, 32 WorLd ECon. 1271,1272 (2009) ("The defining characteristics of what made a firm belong to a country where it was incorporated, where it was listed, the nationality of its investor base, the location of its headquarters functions - are no longer unified nor are they bound to one country.").

19. Since 1999, the European Court of Justice has ruled that the real seat doctrine is incompatible with the freedom of establishment guaranteed by the European Union, favoring the place of incorporation as the relevant choice of law rule. But see infra notes 137-138 and accompanying text.

20. See infra notes 35-36, 220-221 and accompanying text.

21. See, e.g., Detlev F. Vagts, The Corporate Alien: Definitional Questions in Federal Restraints on Foreign Enterprise, 74 HARV. L. REV. 1489, 1505 (1961).

22. FÁbio Konder Comparato \& Calixto Salomão Filho, O Poder de Controle na SOCIEDADE ANÔNIMA 515 (4th ed., 2005). 
Domestic control can also relate to nationalism in instrumental terms - that is, as a tool to increase the welfare of its nationals. Local managers and controlling shareholders benefit from their control powers and stand to gain by avoiding unwanted foreign takeovers. ${ }^{23}$ However, the interests of controllers alone does not explain the popular appeal of nationalism in corporate governance. Why would it matter to the general population that a given firm is in the hands of local rather than foreign elites?

Another more controversial assumption is that domestic control has positive effects over national welfare more generally because of a greater commitment to the local economy in the form of jobs, investment, charitable contributions, and geopolitical allegiance. As discussed in Part II infra, the theoretical arguments and empirical evidence on this question are inconclusive. For now, it is enough to say that the popular appeal of nationalism, the interests of controlling shareholders, managers, and workers, and the presumed benefits to the nation at large constitute a powerful political alliance favoring domestic control of business corporations.

Corporate law can assist in the retention of domestic control in various ways. Structural defenses relying on ownership structures - in the form of multivoting stock, nonvoting stock, voting caps, cross-shareholdings, and shareholder agreements - help prevent a hostile bid ex ante. Takeover defenses such as poison pills thwart hostile acquisitions of firms with dispersed ownership. Countries have also occasionally imposed nationality requirements for corporate directors and managers.

Control nationalism can also lead to state ownership. The primary motivation behind state ownership in many jurisdictions is to maintain corporate control and headquarters on national soil. ${ }^{24}$ Several of the national oil companies (NOCs)which represent the lion's share of global oil reserves - emerged through the expropriation of foreign investors, a product of nationalist sentiment and the political deficit of foreigners. ${ }^{25}$ To this day, governments continue to acquire equity stakes in major firms primarily as a shield against foreign intrusion. ${ }^{26}$ Ownership structures, in turn, are a crucial determinant of corporate laws, given their implications for the efficiency of different legal rules and their influence on the political economy of corporate reforms. ${ }^{27}$

23. Conversely, insulation from hostile takeovers can increase agency costs and hurt domestic public shareholders.

24. See, e.g., infra Sections I.A., I.C., I.G.

25. Paasha Mahdavi, Why Do Leaders Nationalize the Oil Industry? The Politics of Resource Expropriation, 75 ENERGY POL'Y 228, 236-39 (2014) (reporting that NOCs, which emerged through waves of nationalizations, control between seventy-three and ninety-five percent of the world's oil reserves).

26. See, e.g., Helene Fouquet \& Mark Deen, Macron Nationalizes Shipyard, Spooking Outsiders, BlOOMBERG POLITICs (July 27, 2017, 1:23 PM), https://www.bloomberg.com/news /articles/2017-07-27/macron-nationalizes-shipyard-in-domestic-step-spooking-outsiders [https://perma.cc/RVS6-RJ27] (discussing France's recent nationalization of a shipyard in response to a bid by an Italian company).

27. See Armour et al., supra note 9; Bebchuk \& Roe, supra note 3; Mariana Pargendler, State Ownership and Corporate Governance, 80 FoRDHAM L. REV. 2917 (2012) (describing how the state's interests as a shareholder shape corporate laws). Jeffrey Gordon has suggested 
Nationalist forces can also shape corporate law in ways that go beyond the protection of domestic control. Legal nationalism seeks to preserve the application of domestic corporate law to firms operating in a given state. Although there may be other benign justifications for this approach (such as the prevention of a "race to the bottom" in the control of externalities), this serves the different protectionist goals of (i) raising the costs of entry for foreign firms, (ii) creating captive demand for the services of local lawyers and other providers, and (iii) avoiding evasion of corporate laws that are nationalist in substance. The application of the real seat doctrine can therefore be understood as a form of legal nationalism. However, combating legal nationalism through the availability of choice of incorporation state and governing law does not eliminate the influence of control nationalism, since companies often choose to incorporate in their home states, where they have political power and can exercise it in a protectionist manner. ${ }^{28}$

Finally, nationalism can have indirect and serendipitous effects on corporate law and governance. Nationalist regulations in India during the 1960s required foreign companies to divest their stockholdings below forty percent. ${ }^{29}$ This had the indirect effect of promoting the development of Indian capital markets by encouraging multinationals to sell their excess stakes through public offerings. ${ }^{30}$ More broadly, foreign ownership restrictions and governmental controls on foreign investment can greatly decrease the contestability of control in certain countries and industries, thereby compromising the role of takeovers in reducing agency costs and promoting efficient management practices.

The narratives that follow illustrate the grip of nationalism on corporate law and governance across time and place. They cover several prominent jurisdictions over an extended period to show that this phenomenon is longstanding and pervasive. These synopses are not comprehensive. The countries covered have many more instances of nationalist corporate law policies than are discussed below. The selection of jurisdictions is also merely illustrative. While the focus is on jurisdictions that have attracted significant attention in the comparative corporate governance literature, numerous other countries have followed similar patterns. ${ }^{31}$

that ownership structures matter for transnational economic integration, with controlled companies being more susceptible to protectionist behavior than widely held firms subject to hostile takeovers. Companies with entrenched controlling shareholders may continue to pursue inefficient home-country (nationalist) bias in operational decisions, such as the location of factories or R\&D activity. By contrast, the market for corporate control can deter nationalist-inspired inefficiencies in the management of firms with dispersed ownership, since depressed share prices will attract hostile, and possibly foreign, bidders. Gordon, supra note 17 , at 161 .

28. See infra notes 265,288 and accompanying text. Moreover, the very equilibrium resulting from regulatory competition may be influenced by the nationalist or protectionist tendencies of home states. See infra note 290 and accompanying text.

29. Tarun Khanna \& Krishna G. Palepu, The Evolution of Concentrated Ownership in India, in A History of CORPORATE GOVERnANCE AROUND THE World 302 (Randall K. Morck ed., 2007)

30. Id.

31. See, e.g., Randall Morck, Gloria Tian \& Bernard Yeung, Who Owns Whom? Economic Nationalism and Family Controlled Pyramidal Groups in Canada, in Governance, Multinationals And Growth 45-47 (Lorraine Eden \& Wendy Dobson eds., 
To underscore the relevance of nationalism in corporate lawmaking is emphatically not to suggest that it is the only, or even the most important, driving force behind governance structures. Corporate governance arrangements are complex phenomena shaped by a multitude of factors. The goal, instead, is to highlight nationalism as a critical element that has been ignored, downplayed, or dismissed as an aberration.

\section{A. France}

To examine the effect of economic nationalism on the development of corporate laws, let's begin with the case of France, a jurisdiction where nationalist sentiment is particularly strong. The archetypical features of the French system of corporate governance - state ownership and tenured voting rights - are largely attributable to nationalist objectives. The type of overtly protectionist corporate law reforms that have made headlines in the last decades have a long historical pedigree in the country.

Even before the advent of general corporate laws, concerns about foreign control shaped the internal governance rules of major corporations. To avoid external influence, the statutory charter of the Bank of France of 1808 prevented foreigners from attending shareholder meetings and from serving in managerial positions. ${ }^{32}$ All equity interests in the bank took the form of registered shares so that the company could know the nationality of shareholders. ${ }^{33}$ Other large corporations adopted similar arrangements. ${ }^{34}$

Nationalist impulses also influenced the application of the domestic legal regime to local firms. Early French firms sought to circumvent the limitations of the national regime by incorporating in England, which was arguably "the Delaware of the second half of the nineteenth century." 35 Even the Moulin Rouge at some point sought an English charter. ${ }^{36}$ This effort, however, was frustrated by the emerging doctrine of the "real seat" to determine the nationality of corporations, which denied recognition to France-based companies incorporated abroad. Moreover, the attribution of French nationality in certain industries required effective control by French citizens in addition to headquarters in France. ${ }^{37}$

Similarly to other jurisdictions, the regime of shareholder voting rights has also responded to the fear of foreign control. Multivoting stock became popular for the first time in France in the early 1920s, a time in which the devaluation of the franc turned French corporations into vulnerable targets of foreign takeovers. ${ }^{38}$ The French

2005) (exploring the reasons behind the connection between the rise of nationalism and the retreat of widely held firms in Canada); Li-Wen Li \& Curtis J. Milhaupt, We Are the (National) Champions: Understanding the Mechanisms of State Capitalism in China, 65 STAN. L. REV. 697, 746 (2013) (describing how the corporate governance structure of SOE groups in China serves to maximize country-level, rather than firm-level, objectives).

32. MARCEL-EdOUARD CUQ, LA NATIONALITÉ DES SOCIÉTÉS 79 (1921).

33. Id.

34. Id.

35. Elvin R. Latty, Pseudo-Foreign Corporations, 65 YALE L.J. 137, 166 (1955).

36. Id.

37. CUQ, supra note 32 , at $80-81$.

38. Henri Mazeaud, Le Vote Privilégié Dans Les Sociétés de Capitaux 10 (2nd ed., 
government led the way by issuing super voting shares to itself in the Société française de Navigation rhénane and the Compagnie des chemins de fer du Maroc in the $1920 \mathrm{~s} .{ }^{39}$ The state also encouraged the adoption of multivoting stock by private firms as "dictated by the national interest." 40 Scholars at the time specifically justified the use of multivoting stock as a means to ensure French control over companies that were "particularly useful for the development of our country." 41

The unregulated issuance of multivoting stock, highly controversial from the outset, would not be long lasting. In lieu of permitting conventional multivoting stock, France instituted its signature regime of "tenured voting": by charter provision, companies could grant double voting rights to registered shareholders who had held their shares for a certain number of years (typically two years).$^{42}$ While the merits of tenured voting rights from an agency cost perspective are debatable, ${ }^{43}$ this mechanism has the clear effect of strengthening the voting power of the state, which is typically a long-term holder. The ample use of double voting rights, combined with the widespread presence of ownership ceilings, have helped protect France from foreign takeovers in the face of rising levels of foreign ownership in its stock markets. ${ }^{44}$

Despite European Union (E.U.) pressure for liberalization over the last few decades, France has instead promoted several protectionist reforms. The most important corporate law reforms in France in recent years were promulgated as a direct response to high-profile takeover threats from foreign bidders. The mere rumor that PepsiCo would launch a bid for Danone, a cherished conglomerate best known for yogurt products, prompted a renewed defense of "economic patriotism" in France in $2005 .{ }^{45}$ The incident triggered not only the enactment of regulatory protections to "strategic sectors" 46 but also changes in corporate law rules. In the same year, the French securities regulator issued the so-called Danone Amendment to France's

1929).

39. Id.

40. Id. at 51 .

41. Id. at 53 .

42. Harold H. Neff, A Civil Law Answer to the Problem of Securities Regulation, 28 VA. L. REV 1025, 1051 (1942) (describing the adoption of the 1930 and 1933 statutes banning the issuance of stock granting special voting rights).

43. The main justification for tenured voting rights is to avoid short-termism in firm management. For an opposite view on the desirability of tenured voting arrangements, see Jesse M. Fried, The Uneasy Case for Favoring Long-Term Shareholders, 124 YALE L.J. 1554, 1560 (2015).

44. Ben Clift, French Corporate Governance in the New Global Economy: Mechanisms of Change and Hybridisation Within Models of Capitalism, 55 PoL. STUD. 546, 562 (2007) (suggesting that such governance devices have served to "limit foreign capital influence in French firms, replacing the noyaux durs").

45. Clift \& Woll, supra note 4 , at 321.

46. Décret 2005-1739 du 30 décembre 2005 réglementant les relations financières avec l'étranger et portant application de l'article L. 151-3 (V) du code monétaire et financier [Decree 2005-1739 of December 30, 2005 Regulating Financial Relations with Foreign Countries and Implementing Article L. 151-3 (V) of the Monetary and Financial Code], Journal OfFiciel de la RÉPubliQue Française [J.O.] [OfFicial GaZetTe of France], Dec. 31, 2005, p. 20779. 
Takeover Code, requiring rumored bidders to state their intentions early in the process and either "put up or shut up" (i.e., either make an offer promptly or refrain from doing so for a period of six months). ${ }^{47}$

The traumatic hostile takeover of French steel champion Arcelor by the Indian group Mittal in 2006 - which succeeded despite strong political opposition-was particularly consequential from a legal standpoint. In the same year, France introduced its first type of shareholder rights plan to deter takeovers, which was nicknamed "bons Breton" (for the finance minister who sponsored it) or, more revealingly, "bons patriotes." ${ }^{48}$ In 2014, the French parliament promulgated the openly protectionist loi Florange (to "reconquer the real economy"), in a reference to the controversial closure by Arcelor Mittal of an industrial plant in the city of Florange in $2012 .^{49}$

In addition to requiring companies to make every effort to find a buyer before closing a plant, the loi Florange made several encroachments into corporate law. The loi Florange abandoned France's no-frustration rule and permitted prebid approval of shareholder rights plans, hence enabling shareholders to commit to incumbent management. ${ }^{50}$ The new statute also strengthened the information and consultation rights of employees in ways that could slow down the process and even deter takeover bids. $^{51}$

Finally, the statute reversed the existing default rule by imposing the automatic grant of double voting rights to shares held for at least two years, unless shareholders opted out by a two-thirds majority vote. This change explicitly aimed to preserve or enhance the influence of the French state in companies of strategic importance while permitting it to divest some of its stockholdings to pay off mounting national debt. ${ }^{52}$ While most firms reverted to the old default rule of proportional voting following the reform, companies with significant state shareholdings-mostly national champions-some saw the adoption of double voting rights, as the state often acquired shares in the market to block a reversal. ${ }^{53}$ The French government expressly argued that its exercise of voting rights would allow it to "strengthen the coherence between the state's strategy for the country and that put into effect by each company with state shareholdings." 54

47. Arnauld Achard, Takeover Bid Directive: Implementation in France, LEXOLOGY (Oct. 4, 2011), https://www.lexology.com/library/detail.aspx?g=c651e3e1-af04-4be5-9808-0f5 d2ec7275d [https://perma.cc/XQ39-NXGB].

48. For a discussion of their properties, see Paul Davies, Klaus Hopt \& Wolf-Georg Ringe, Control Transactions, in ANATOMY OF CORPORATE LAW, supra note 9, at 216-17.

49. See Loi 2014-384 du 29 mars 2014 visant à reconquérir l'économie réelle No. 2014384 of 29 March 2014 [Law Number 2014-384 of March 29, 2014 Aiming at Reconquering the Real Economy] ("Loi Florange"), https://www.legifrance.gouv.fr/affichTexte.do?cidText e=JORFTEXT000028811102 [https://perma.cc/S2RF-KFSB].

50. Davies et al., supra note 48 , at 216.

51. Id. at 209 .

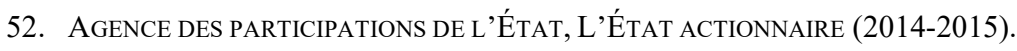

53. Marco Becht, Yuliya Kamisarenka \& Anete Pajuste, Loyalty Shares - A Coasian Bargain? Evidence from the Loi Florange Experiment 20 (European Corp. Governance Inst., Working Paper No. 398/2018, 2018).

54. AGENCE DES PARTICIPATIONS DE L'ÉTAT, supra note 52 (preface). 
State ownership has periodically emerged with the immediate goal of keeping national champions under French control..$^{55}$ The control battle over power company Suez is illustrative. In order to fend off a bid by Italian competitor Enel, the French government promoted a merger between Suez and state-controlled GDF. The transaction faced significant opposition from the left: it led to GDF's privatization in contradiction to prior promises made to trade unions, though the state retained a thirty-five percent interest in the combined firm. ${ }^{56}$ The episode shows that the general popular impetus to uphold domestic control is often stronger than ideological and special interest preferences for state ownership.

More recently, the French government proposed a series of reforms to the Civil Code with the goal of mitigating the perceived financialization and short-term orientation of French corporate governance, allegedly inspired by Anglo-Saxon practices. ${ }^{57}$ The proposed legislation seeks to overcome the focus on shareholder value by specifying that "the company shall be managed in its own interest, considering the social and environmental consequences of its activity" and increasing the participation of workers on company boards. ${ }^{58}$ In contrast to the prevailing predictions in the literature, this proposed shift away from shareholder value appeared in the context of strong foreign participation in French capital markets, ${ }^{59}$ with the official report specifically referring to the presence of "Anglo-Saxon funds" in its introduction. ${ }^{60}$

\section{B. Germany}

Corporate laws and practices in Germany have also been particularly responsive to nationalist sentiment. As in France, the expansion of multivoting stock after World War I took place in connection with the fear of foreign takeovers due to the depreciation of the German mark. ${ }^{61}$ Apprehension about potential foreign influence swayed public opinion and German courts, which generally declined to interfere even as firms began issuing high-vote preference shares at extraordinary multiples. ${ }^{62}$ Although the protection of German ownership was the main justification for the

55. For a recent episode, see supra note 26 and accompanying text.

56. For a discussion, see Ilene Knable Gotts, Caveat Emptor: Transaction Parties Need to Consider Foreign Investment Laws as Part of Pre-Deal Planning, in InTERnational Antitrust Law And Policy: Fordham Competition Law 173 (Barry E. Hawk ed., 2014).

57. Nicole Notat \& JeAn-Dominique Senard, L'entreprise, objet d'intérêt COLLECTIF 3 (2018).

58. Id. at 6-7.

59. See infra Table A and accompanying text.

60. NOTAT \& SENARD, supra note 57, at 3.

61. A. B. Levy, Private Corporations and Their Control I 170 (Karl Mannheim ed., 1950).

62. Id. at 171; Wolf-Georg Ringe, Deviations from Ownership-Control ProportionalityEconomic Protectionism Revisited, in COMPANY LAW AND ECONOMIC PROTECTIONISM: NEW Challenges to European Integration, supra note 6, at 217 (citing multiples of hundreds or thousands of votes per share). 
practice, multivoting stock also gained ground in firms that did not face plausible foreign threats. ${ }^{63}$

Subsequent laws during the Nazi regime, as well as the Corporations Law of 1965, restricted the use of multivoting stock as takeover threats subsided, though certain exceptions remained ${ }^{64}$ In the 1970s, when German companies once again became vulnerable to foreign takeovers fueled by oil dollars from the Middle East, multivoting shares and voting caps experienced a renaissance as defensive devices. ${ }^{65}$ It was not until the liberalizing Law on Transparency and Control in Corporations (Gesetz zur Kontrolle und Transparenz im Unternehmensbereich - KonTraG) of 1998 that German law prohibited voting caps and multivoting stock. ${ }^{66}$

While the abolition of control-enhancing devices faced considerable resistance in other European countries, it surprisingly enjoyed the support of the German establishment. ${ }^{67}$ Yet the enthusiasm for greater market discipline would not be long lasting once the new vulnerability of German firms to foreign bidders became apparent. The groundbreaking takeover of traditional German telecom Mannesmann by British firm Vodafone in 1999-in what was the first successful hostile tender offer by a foreign bidder in the country's history-strengthened nationalist sensitivities. ${ }^{68}$ Having made its local firms vulnerable after dismantling structural protections through corporate reforms, Germany then became a formidable opponent to the board neutrality provision in the Takeover Directive, which was ultimately rendered optional. ${ }^{69}$ Germany's Takeover Act of 2002 professed to support board neutrality, but in reality permits the employment of defensive measures approved by the supervisory board. ${ }^{70}$

Finally, Germany's signature regime of worker representation on corporate boards also has a distinctive nationalist flavor. In the German system of "quasi-parity codetermination," employee directors comprise half the members of the supervisory boards of companies with more than 2,000 Germany-based employees. ${ }^{71}$ Not only are workers generally inclined to oppose foreign takeovers but German law also specifically restricts the right to appoint labor directors to Germany-based employees

63. LEVY, supra note 61 , at 171.

64. Caroline Fohlin, The History of Corporate Ownership and Control in Germany, in A History OF CORPORATE GOVERNANCE AROUND THE WORLD 262 (Randall K. Morck ed., 2005).

65. Id. at 263 (multivoting shares); Thomas J. André, Jr., Cultural Hegemony - The Exportation of Anglo-Saxon Corporate Governance Ideology to Germany, 73 TUL. L. REV. 69, 168 (1998) (voting caps).

66. Ulrich Seibert, Control and Transparency in Business (KonTraG): Corporate Governance Reform in Germany, 10 EuR. Bus. L. REV. 70, 72 (1999).

67. Id.

68. Gordon, supra note 17, at 187-89, 195-97.

69. See infra notes 149-150 and accompanying text.

70. Davies et al., supra note 48, at 219-20 (noting that employee representatives on a codetermined board will tend to favor the interests of managers over those of shareholders).

71. Mitbestimmungsgesetz [Law on Employee Participation], May 1976, BGBL I at 1153, $\S \S 1 \& 7$ (W. Ger.). 
and trade unions. ${ }^{72}$ This differential treatment of foreign employees has recently withstood a challenge before the European Court of Justice (ECJ). ${ }^{73}$

\section{Scandinavia and Switzerland}

Nationalist and protectionist pressures have also profoundly influenced other European countries. Take the case of Sweden, a country that has strongly (and successfully) opposed both the move to a "one-share-one-vote" standard at the E.U. level and the introduction of a mandatory "breakthrough rule" in the Takeover Directive. ${ }^{74}$ Scholars have long debated the motivation for high levels of ownership concentration in Sweden, a jurisdiction where controlling shareholders coexist with a legal regime that reasonably protects outside investors. Ronald Gilson attributes the dominance of controlling shareholders in Sweden to the nonpecuniary private benefits of control, such as social status, enjoyed by the dominant families in a small jurisdiction. ${ }^{75}$ Mark Roe argues that social democracies go hand-in-hand with ownership concentration, so that large shareholders can counterbalance labor pressures. $^{76}$

Peter Högfeldt's case study on the evolution of corporate governance in Sweden, however, highlights the nationalist dimension of the symbiotic relationship between social democracy and concentrated ownership. "The Social Democrats," he explains, "only get the necessary resources and indirect support for their social and economic policies from the private sector if the largest firms remain under Swedish control so that capital does not migrate." 77 At the same time, Sweden's wealthy families have regarded support for social democratic policies as a small price to pay for their continued grip on corporate control. ${ }^{78}$

Significant restrictions on foreign ownership have historically been an integral part of the Swedish model, with profound implications for governance structures. ${ }^{79}$ Foreign ownership of Swedish corporations was limited to special "unrestricted shares" having at most twenty percent of voting rights, while "restricted shares" could only be held by Swedish individuals and institutions. ${ }^{80}$ To reconcile this limitation with the need to raise substantial amounts of foreign capital, some Swedish

72. See Luca Enriques, Henry Hansmann, Reinier Kraakman \& Mariana Pargendler, The Basic Governance Structure: Minority Shareholders and Non-Shareholder Constituencies, in AnATOMy of Corporate LAW: A COMPARATIVE AND Functional Approach, supra note 9, at 91 .

73. Case C-566/15 Erzberger v TUI AG, judgment of July 18, 2017.

74. Rolf Skog, The European Union's Proposed Takeover Directive, The "Breakthrough" Rule and the Swedish System of Dual Class Common Stock, in SCANDINAVIAN STUdiES IN LAw 298 (2004).

75. Ronald J. Gilson, Controlling Shareholders and Corporate Governance: Complicating the Comparative Taxonomy, 119 HARV. L. REV. 1641, 1645 (2006).

76. Mark J. Roe, Political Determinants of Corporate Governance: Political CONTEXT, CORPORATE IMPACT 96 (2006).

77. Peter Högfeldt, The History and Politics of Corporate Ownership in Sweden, in A History OF CORPORATE GOVERNANCE AROUND THE World 522 (Randall K. Morck ed., 2007).

78. Id.

79. Id. at 534 .

80. Id. 
firms like Ericsson and SKF resorted to an extreme separation of voting and cash flow rights in the form of B-shares carrying a 1/1000 voting right. ${ }^{81} \mathrm{~A}$ legal reform in 1944 established a maximum multiple of ten votes per share but grandfathered existing firms, to the effect that Ericsson continued issuing shares with 1/1000 of a voting right into the twenty-first century. ${ }^{82}$

Foreign ownership of listed companies increased dramatically as foreign restrictions were lifted in 1993 in view of E.U. membership, but other governance substitutes emerged in the form of greater reliance on multivoting shares to ensure continued Swedish control. ${ }^{83}$ Foreign investors have repeatedly decried this system as "an example of Swedish ultranationalism." However, the government's policy on this issue remains unchanged. ${ }^{84}$

Nationalist policies have also played a major part in the corporate governance landscape in Norway and Switzerland, which are not formal members of the E.U. Norway limited foreign ownership in public companies to thirty-three percent of the voting shares until the free trade accord of the European Economic Area (EEA) imposed equal treatment to foreign investments in $1995 .{ }^{85}$ Seeking to attract foreign capital while abandoning the foreign ownership restrictions, Norwegian companies began issuing a significant number of nonvoting shares to the public. ${ }^{86}$

Norway also stands out for its embrace of state ownership, with levels that are the highest among developed countries and comparable to those of emerging markets. ${ }^{87}$ Held as a model in state-owned enterprise (SOE) governance, Norway's commitment to state shareholdings is in large part driven by the desire to retain local control over important industries. Six of the eight Norwegian SOEs listed on the Oslo Stock Exchange have as their declared purpose, beyond a return on investment, the retention of head office functions in Norway. ${ }^{88}$

In contrast to Norway and Sweden, Switzerland has traditionally eschewed foreign ownership restrictions and other forms of regulatory discrimination against foreign investors. ${ }^{89}$ Switzerland instead provides a paradigmatic example of the use of corporate law as stealth protectionism, showing how nationalist constraints

81. Id.

82. Gerhard Schnyder, Does Social Democracy Matter? Corporate Governance Reforms in Switzerland and Sweden (1980 - 2005) 18 (Ctr. for Bus. Res., Univ. of Cambridge, Working Paper No. 370, 2008).

83. Högfeldt, supra note 77, at 535. But see Skog, supra note 74, at 303 (contending that foreign takeovers have risen since the lifting of foreign ownership restrictions in Sweden).

84. Joakim Reiter, Changing the Microfoundations of Corporatism: The Impact of Financial Globalisation on Swedish Corporate Ownership, 8 NEW PoL. ECoN. 103, 117 (2003).

85. Bernt Arne Ødegaard, Price Differences Between Equity Classes: Corporate Control, Foreign Ownership or Liquidity?, 31 J. BANK. \& FIN. 3621, 3627 (2007).

86. Id. at 3628 .

87. Thomas Dowling et al., Norway: Selected Issues, IMF Country Report No. 14/260 (2014), https://www.imf.org/en/Publications/CR/Issues/2016/12/31/Norway-Selected -Issues-41874 [https://perma.cc/W6MW-MEKJ].

88. See Curtis Milhaupt \& Mariana Pargendler, Governance Challenges of Listed StateOwned Enterprises Around the World: National Experiences and a Framework for Reform, 50 CORNELL INT'L L.J. 473 (2017).

89. Peter J. Katzenstein, Corporatism And Change 156 (1987). 
embedded in corporate law can assist a country in attaining a "cosmopolitan image" that is nevertheless "deceptive." "striking incongruity" between major protectionist barriers against foreign takeovers with the aggressive pursuit of foreign targets by Swiss companies. ${ }^{91}$

For a long time, a panoply of corporate law mechanisms rendered Swiss companies effectively takeover proof against foreign bidders. ${ }^{92}$ Until the $1990 \mathrm{~s}$, most Swiss corporations had charter provisions prohibiting ownership of registered shares (as opposed to bearer shares) by foreign investors, while bearer shares lacked the right to vote. ${ }^{93}$ When companies began abolishing these voluntary foreign ownership restrictions in the 1980s to attract international capital, they then started imposing strict ownership caps as a takeover defense. ${ }^{94}$ Until 2008, corporate law required a majority of board members to be Swiss nationals and reside in Switzerland. ${ }^{95}$

Historically, the most formidable and distinctive takeover defense under Swiss law has been the Vinkulierung, which is the charter provision granting the board of directors full discretion to deny registration (and therefore the exercise of shareholder rights) to transferred shares for any reason..$^{96}$ Used at least since the 1920 s to "curb a perceived excessive foreign influence on Swiss companies,"97 the Vinkulierung gained ground during World War II as a mechanism to avoid Nazi control of corporations and placement on an "enemy list." that the primary purpose of the Vinkulierung was to "limit the influence of foreign investors on Swiss companies." 99

Nestlé led the way in eliminating its own charter restrictions on foreign ownership in 1988, but only after its takeover of U.K. firm Rowntree generated significant controversy and fear of retaliation in view of its own defenses against foreign acquirers. ${ }^{100}$ Although a 1991 reform restricted the scope of Vinkulierung, ${ }^{101}$ the mechanism is still permissible by law and occasionally present in corporate practice

90. Id.

91. See also Rebecca G. Peters, Protection Against Hostile Takeover and the Exercise of Shareholder Voting Rights in Switzerland, 11 U. PENN. J. InT’L L. 519 (1990).

92. KATZENSTEIN, supra note 89, at 157 ("It appears to be virtually impossible for a nonSwiss to take over one of Switzerland's resident corporations.”).

93. Peters, supra note 91, at 529.

94. Nestlé, for instance, capped the ownership of registered shares at three percent of total capital for both Swiss and foreign investors. Id. at $524 \mathrm{n} .23$.

95. Peter V. Kunz, Switzerland: The System of Corporate Governance, in ComParative Corporate Governance: A Functional and International Analysis 879 (Andreas M. Fleckner \& Klaus J. Hopt eds., 2013).

96. See Peters, supra note 91, at 531-32.

97. Gerhard Schnyder \& Frédéric Widmer, Swiss Corporate Governance: Institutional Change in the Law and Corporate Practices, in Switzerland In Europe 109 (Christine Trampusch \& André Mach eds., 2011).

98. Peters, supra note 91, at 541.

99. Schnyder, supra note 82 , at 15.

100. Id. at 66 .

101. Id. at 15 . Schnyder notes that " $[\mathrm{t}]$ he debates which took place in the parliament clearly show that this provision was aimed at maintaining the possibility of excluding foreign investors from Swiss companies - the traditional aim of Vinkulierung - without stipulating explicitly in the law that nationality could be a reason for refusal." Id. at 16. 
up to this day. ${ }^{102}$ While Swiss corporations are currently far more vulnerable to hostile acquisitions than in the past, foreign takeover threats continue to prompt protectionist legal reforms. ${ }^{103}$

\section{United Kingdom}

The United Kingdom stands out for its particularly vibrant market of corporate control and liberal takeover laws, which have long embraced the principle of board neutrality in the face of a hostile bid. ${ }^{104}$ Various factors may help account for the United Kingdom's greater openness to foreign capital. England industrialized before other countries and therefore was first able to abandon protectionist practices to promote an infant domestic industry. ${ }^{105}$ It also came to boast an especially developed financial sector which stood to gain from cross-border acquisitions and strong institutional investors who favored an active takeover market. Its liberal market economy was not as easily disrupted by hostile takeovers as the coordinated market economies of continental Europe. ${ }^{106}$ Moreover, having a unitary political system, it was immune from the type of state-level protectionism that tarnished the development of U.S. takeover laws. ${ }^{107}$

Nationalism, however, still left its mark on U.K. company law and governance. With the eruption of World War I, new restrictions to trading with the enemy put pressure on two core tenets of U.K. corporate law: the strict separation between the company as an entity and its shareholders and the place of incorporation as the determinant of a company's domicile and applicable law. In its famous 1916 decision in Daimler Co. v. Continental Tyre \& Rubber Co., the House of Lords was willing to upset both canons by holding that a company chartered in England nonetheless qualified as an enemy because its directors and shareholders were German and resided in Germany. ${ }^{108}$ The decision, which served national security rather than agency cost concerns, appears to provide the first judicial articulation of the concept of corporate control. ${ }^{109}$

Takeovers of major companies have also occasionally raised eyebrows. The acquisitions of Ford U.K. by Ford U.S.A. and of Rootes by Chrysler, triggered government scrutiny in the 1960s. The deals only went ahead once the new owners committed to maintain the companies" "Britishness," through mechanisms such as a minimum number of U.K. directors and an increase in export targets to assist the

102. See Kunz, supra note 95 , at 909.

103. Id. at 874 n.37 (noting how hostile takeover attempts by foreign firms led to swift changes to securities laws in the 2000s).

104. See John Armour \& David A. Skeel, Jr., Who Writes the Rules for Hostile Takeovers, and Why? - The Peculiar Divergence of U.S. and U.K. Takeover Regulation, 95 GEO. L.J. 1727, 1775 (2007); see also Davies et al., supra note 48, at 221.

105. Ha-Joon Chang, Kicking Away the Ladder: The "Real" History of Free Trade, FOREIGN POLICY IN FOCUS (Dec. 30, 2003), https://fpif.org/kicking_away_the_ladder_the_real _history_of_free_trade/[https://perma.cc/JYC2-7KG2].

106. For an elaboration of this argument, see infra note 310 and accompanying text.

107. See infra Section II.H.

108. [1916] 2 AC 307 (Lord Parker of Waddington).

109. COMPARATO \& SALOMÃo FILHO, supra note 22, at 515. 
national balance of payments. ${ }^{110}$ In response to these foreign takeovers, the government promoted a merger between BMC and Leyland to create a larger and more competitive car company that was entirely British. ${ }^{111}$ In 1981, when the Hongkong and Shanghai Banking Corporation (HSBC) attempted to acquire the Royal Bank of Scotland, the Bank of England opposed the transaction by arguing that RBS should remain "British." 112 The Monopolies and Mergers Commission ultimately vetoed the transaction as contrary to the public interest for quintessentially nationalist reasons. ${ }^{113}$ Although it ultimately proceeded without regulatory objection, the takeover of chocolate maker Rowntree by Nestlé in 1986 generated heated parliamentary debate on the harm to Britain's national interest and the lack of reciprocity given the Swiss company's insulation from foreign acquisitions. ${ }^{114}$

The U.K.'s historical approach to foreign takeovers has been far from hands off, though still quite receptive compared to other jurisdictions. However, this welcoming attitude has been changing fast. The hostile takeover of Cadbury by Kraft, a U.S. food giant, was particularly consequential in reviving anxiety about foreign acquisitions and prompting the United Kingdom to revisit its liberal takeover laws.

Cadbury was an iconic U.K. firm, ${ }^{115}$ though by the time of the takeover only a fraction of its workforce was located in Britain. ${ }^{116}$ Not only did Cadbury fall into foreign hands, but Kraft also added insult to injury by reneging on a promise to keep open a Somerdale factory within days of completing the acquisition. ${ }^{117}$ This reversal of position leading to the relocation of the factory to Poland generated significant public and parliamentary uproar and resulted in a formal statement of public criticism by the Takeover Panel. ${ }^{118}$ The incident also triggered two inquiries by the House of

110. Lukas Andreas Linsi, How the Beast Became a Beauty: The Social Construction of the Economic Meaning of Foreign Direct Investment Inflows in Advanced Economies, 19602007, at 249 (Aug. 2016) (unpublished Ph.D. dissertation, London School of Economics and Political Science) (on file with the Indiana Law Journal).

111. Id. at 250 .

112. Id. at 261 .

113. Id.; see also BARry J Rodger \& Angus MacCulloch, COMPetition LAW AND POLICY IN THE EC AND UK 329 (4th ed. 2009) ("The Commission found the proposed mergers to be likely to operate against the public interest due to the removal of ultimate control from Edinburgh, the importance of the company and the industry in Scotland, the reduction of career opportunities in Scotland and the fears, generally, over the creation of a branch economy.").

114. See supra note 100 and accompanying text.

115. Cadbury's long-time chairman, Sir Adrian Cadbury, led the effort in the 1990s to produce the United Kingdom's landmark Code of Best Practice on Corporate Governance, known as the Cadbury Code. For a discussion of Cadbury's distinguished corporate history since the nineteenth century, see COLIn MAYER, Firm COMmitment 79-82, 93 (2013) (describing the firm's founding by Quakers and the promotion of ethical values such as by building the town of Bournville for its employees).

116. See Cadbury Accepts \$21.8B Takeover by Kraft, CNN (Jan. 19, 2010, 12:24 PM), http://www.cnn.com/2010/BUSINESS/01/19/kraft.cadbury/index.html [https://perma.cc /T38L-DDBJ] ("The company now employs around 45,000 people in 60 countries, including around [5700] staff at eight manufacturing sites in the UK and Ireland[.]").

117. Ben Morris, The Cadbury Deal: How It Changed Takeovers, BBC (May 2, 2014), https://www.bbc.com/news/business-27258143 [https://perma.cc/LMK4-V27M].

118. Panel Statement from the Takeover Panel on Kraft Foods Inc. Offer for Cadbury PLC 
Commons in which Kraft agreed to several undertakings, ranging from the preservation of jobs and work conditions in the United Kingdom to the continued sponsorship of the London Olympics. ${ }^{119}$ The House of Commons subsequently published a report entitled Is Kraft Working for Cadbury? to assess whether the U.S. firm was meeting its undertakings - a clear instance of bullying against a foreign buyer. ${ }^{120}$

The political reaction against foreign takeovers was sufficiently strong to induce the Takeover Panel - which is run by investment bankers in the city and oriented towards the interests of shareholders - to enact rules that for the first time considered the interests of employees. It included provisions that strengthened the "put up or shut up" rule, banned deal protections such as break-up fees, and imposed enhanced disclosure requirements to help dissuade takeover activity. ${ }^{121}$ Significantly, the Takeover Code now compels bidders to disclose their intention with respect to employment, conditions of employment, and the company's place of business and headquarters; requires target boards to give their views with respect to the effects of the bid on these matters; and enables employee representatives and pension scheme trustees to issue a separate opinion on the effects of the bid on employment and pension schemes. ${ }^{122}$

The hostile takeover bid launched by Pfizer, a U.S. firm, against U.K. pharmaceutical giant AstraZeneca in 2014 again produced strong political resistance and provoked further changes to the Takeover Code. The House of Commons asked Pfizer's CEO for assurances about the preservation of jobs and research and development investments in the U.K. during the course of the offer, but there was uncertainty about whether such commitments would be legally binding. ${ }^{123}$ In response, the Takeover Panel again amended its rules to permit bidders to make enforceable "post-offer undertakings" about their course of action following the acquisition, in addition to nonbinding "statements of intentions," to assuage politicians and the public about the consequences of foreign acquisitions. ${ }^{124}$ In 2016, Japanese firm SoftBank made use of a postoffer undertaking for the first time in its U.S. $\$ 32$ billion buyout of U.K. chip designer ARM Holdings, promising to double

(May 26, 2010), http://www.thetakeoverpanel.org.uk/wp-content/uploads/2009/12/2010 -14.pdf [https://perma.cc/4WYR-TZ5Y] (finding that Kraft did not meet the required standard of care in the formulation of its original statement).

119. Business, InNovation And Skills Committee, Is KRAFt Working For CAdBury?, 2010-12, HC 871, at 3, 6 (UK).

120. Id.

121. David Kershaw, Corporate Law and Self-Regulation, in OXFORD HANDBOOK ON Corporate LAW AND GovernANCE 880 (Jeffrey N. Gordon \& Wolf-Georg Ringe eds., 2015).

122. The City Code on Takeovers and Mergers (2016), Rules 2.7, 2.11, 24.2 and 25.2.

123. Graeme Wearden, Pfizer-AstraZeneca: MPs Question Pharma Chiefs on Takeover, GUARDIAN (May 13, 2014, 11:36 AM), https://www.theguardian.com/business/blog/2014 /may/13/pfizer-astrazeneca-mps-grill-pharma-chiefs-over-takeover-live [https://perma.cc/A7FT-X3ZZ].

124. Gillian Fairfield, Statements of Intention Under the UK Takeover Code - Say What You Mean and Do What You Say, Herbert Smith Freehills (Nov. 28, 2014), https:/www.herbertsmithfreehills.com/latest-thinking/statements-of-intention-under-the-uktakeover-code---say-what-you-mean-and-do-what [https://perma.cc/3TDF-KSZC]. 
ARM's employee headcount in the United Kingdom and to maintain its headquarters in Cambridge for five years. ${ }^{125}$

A hostile bid by Kraft for Anglo-Dutch giant Unilever, which faced political resistance, ${ }^{126}$ sparked new calls for changes to the Takeover Code. ${ }^{127}$ Prime Minister May's Conservative Manifesto of 2017 vowed to reform the rules on takeovers and mergers. ${ }^{128}$ Even The Economist, a pro-market publication, has reversed its views on foreign acquisitions. While recent editions had decried protectionist tendencies and touted the benefits of free takeover markets, ${ }^{129}$ a 2017 editorial showed a clear change of heart, expressly disputing the analogy between free trade and the market for corporate control because "having a critical mass of global firms matters." ${ }^{130}$ It argued that "there is a finite stock of big global companies that is hard to replace," so that "Britain probably could not create a new drugs giant if AstraZeneca were bought." ${ }^{\prime 131}$ A subsequent amendment to the Takeover Code in 2018 further increased disclosure requirements concerning the bidder's intentions with respect to the target's research and development functions and the location of its headquarters. ${ }^{132}$

The growing fear of foreign takeovers is leading the United Kingdom to reevaluate the core tenets of its takeover policy. ${ }^{133}$ This shows that friendly attitudes to foreign control are not durable but are instead inherently unstable and susceptible to political change.

125. Sean Farrell \& Julia Kollewe, ARM Shareholders Approve SoftBank Takeover, GUARDiAn (Aug. 30, 2016, 12:56 PM), https://www.theguardian.com/business/2016/aug/30 /arm-shareholders-softbank-takeover-tech-lord-myners [https://perma.cc/843T-VSUK].

126. Arash Massoudi \& James Fontanella-Khan, The \$143bn Flop: How Warren Buffett and $3 G$ Lost Unilever, FIN. TIMES (Feb. 21, 2017), https://www.ft.com/content/d846766ef81b-11e6-bd4e-68d53499ed71 [https://perma.cc/8L3W-835F].

127. Scheherazade Daneshkhu, Jim Pickard \& Arash Massoudi, Unilever Calls for Revamp of UK Takeover Code After Kraft Bid, Fin. Times (Mar. 14, 2017), https://www.ft.com/content /f85e6438-08b1-11e7-ac5a-903b21361b43 [https://perma.cc/E9PM-PRGF].

128. The Conservative And Unionist PARTy MANifesto 2017, at 17, https://s3.eu-west2.amazonaws.com/conservative-party-manifestos/Forward+Together+-+Our+Plan + for $+\mathrm{a}$ + Stronger+Britain+and+a+More+Prosperous....pdf [https://perma.cc/C6W3-57X7].

129. Fear and Favour: Foreign Takeovers, ECONOMIST (July 23, 2016), https://www.economist.com/britain/2016/07/23/fear-and-favour [https://perma.cc/H6V65LQF]; Small Island for Sale: Foreign Takeovers in Britain, ECONOMIST (Mar. 25, 2010), https://www.economist.com/briefing/2010/03/25/small-island-for-sale [https://perma.cc/2RGZ-W8WD].

130. Britain Has Second Thoughts About Foreign Takeovers: A Lack of Big Multinational Companies Does Not Bode Well for the Post-Brexit Economy, ECONOMIST (Mar. 2, 2017), https://www.economist.com/business/2017/03/02/britain-has-second-thoughts-about-foreigntakeovers [https://perma.cc/TM55-6RDC] ("The analogy with free trade, which would suggest that resources swiftly get reallocated from big dying firms to fast-growing ones, is not straightforward when applied to the market for corporate control.").

131. Id.

132. Response Statement by the Code Committee of the Takeover Panel on Statements of Intention and Related Matters 4 (Dec. 11, 2017), http://www.thetakeoverpanel.org.uk/wp -content/uploads/2017/12/FinalRS2017-2.pdf [https://perma.cc/9R68-NXXA].

133. Id. ("Britain's 30-year experiment with a free market for takeovers is quietly coming to an end."). 


\section{E. European Union}

The European Union has been deeply involved in the regulation of corporate law in the last several decades. While corporate lawmaking at the E.U. level aims to promote a variety of policy objectives, there is little question that the promotion of economic integration - and the related goal of removing barriers to cross-border consolidations - reigns supreme. ${ }^{134}$ The reduction in agency costs and the promotion of capital market efficiency has played at best a secondary role.

The various E.U. initiatives on corporate law are noteworthy as the first and only multilateral effort to promote economic integration by curbing the use of corporate law for protectionist purposes. The European Union guarantees four freedoms: the free movement of goods, services, establishment, and capital. Policymakers soon recognized that corporate law could easily impinge on the latter two, to the effect that European company law came to be held as a "cornerstone of the internal market." 135 To further economic integration, E.U. corporate law aims to eliminate protectionist barriers to the market for corporate control, reduce the costs of compliance with different legal standards, and avoid a possible regulatory "race to the bottom."136

The European Union's track record in lifting corporate law barriers to freedom of capital and freedom of establishment is mixed and underscores the political and conceptual challenges plaguing efforts to overcome the grip of nationalism on corporate law. While the European Court of Justice (ECJ) helped curb nationalist tendencies by outlawing the real seat doctrine and most uses of golden shares, the Takeover Directive's legislative attempt to remove protectionist barriers to an internal market for corporate control is widely regarded as a failure. I will examine each in turn.

A key development in E.U. corporate law since the turn of the twentieth century has been the rise of choice of law. Prior to the ECJ's intervention, most member States embraced the real seat doctrine, which required corporations to be governed by the corporate laws of the jurisdiction of their principal place of business. The real seat doctrine thus foreclosed choice of law. ${ }^{137}$

134. See Martin Gelter, EU Company Law Harmonization Between Convergence and Varieties of Capitalism 33 (European Corp. Governance Inst., Working Paper No. 355/2017, 2017) ("Throughout all periods [since the 1960s], EU company law harmonization was largely a top-down, technocratic project that was considered imperative to realize the common market.").

135. Communication from the Commission to the European Parliament, the Council, the European Economic and Social Committee and the Committee of the Regions, Action Plan: European Company Law and Corporate Governance - A Modern Legal Framework for More Engaged Shareholders and Sustainable Companies, at 4, COM (2012) 740 final (Dec. 12, 2012).

136. See Martin Gelter, Centros, the Freedom of Establishment for Companies and the Court's Accidental Vision for Corporate Law, in EU LAW STORIES (Fernanda Nicola \& Bill Davies eds., 2017).

137. More precisely, the real seat doctrine tied the choice of law to the choice of the principal place of business, making a change in the applicable law impossible in the absence of a relocation (and, therefore, making it inordinately expensive). 
In Centros Ltd. v. Erhvervs-og Selskabsstyrelsen and its progeny, ${ }^{138}$ the ECJ held that the real seat doctrine was inconsistent with the E.U. principle of freedom of establishment, which permits companies to incorporate in any member State of their choosing. Actual competition among member States for corporate charters still appears to be rather limited, with no "European Delaware" emerging to date. ${ }^{139}$ Nevertheless, the ECJ cases arguably induced member States to eliminate their minimum capital requirements for private companies - a long-established feature of Continental company law - in an attempt to halt the flight of start-ups to the United Kingdom, which lacked similar rules. ${ }^{140}$

In addition to combating legal protectionism that prevented choice of law, E.U. law has also tried to curb control protectionism in the form of golden shares and takeover defenses. First created during the U.K. privatizations in the 1980s, golden shares essentially grant the government veto rights over fundamental corporate decisions (such as mergers, asset sales, and dissolutions) that are disproportionate to, or even independent of, its cash flow rights in the company. The rationale for the award of golden shares is presumably to protect the public interest at large, though the government's intervention formally takes place through mechanisms of corporate law. ${ }^{141}$ In a series of pivotal decisions since 2002, the ECJ has systematically invalidated the use of golden shares by member States as a violation of free movement of capital. ${ }^{142}$ The ECJ golden shares jurisprudence is momentous both for outlawing an important mechanism for the protection of national industry and for its potentially broad implications for E.U. scrutiny of company law. ${ }^{143}$

138. Case C-212/97, Centros Ltd. v. Erhvervs-og Selskabsstyrelsen, 1999 E.C.R. I-1459; see also Case C-210/06, Cartesio Oktató és Szolgáltató bt, 2008 E.C.R. I-9641; Case C167/01, Kamer van Koophandel en Fabrieken voor Amsterdam v. Inspire Art Ltd, 2003 E.C.R. I-10155; Case C-208/00, Überseering BV v. Nordic Constr. Co. Baumanagement GmbH, 2002 E.C.R. I-9919.

139. For a discussion of the factors hampering regulatory competition in Europe, see Martin Gelter, The Structure of Regulatory Competition in European Corporate Law, 5 J. CORP. L. STUD. 247 (2005).

140. Wolf Georg-Ringe, Corporate Mobility in the European Union-A Flash in the Pan? An Empirical Study on the Success of Lawmaking and Regulatory Competition, 10 EUR. COMPANY \& FIN. L. REV. 230 (2013) (casting doubt on the vigor of regulatory competition in the European Union after Centros).

141. However, when the U.K. government argued that golden shares were a mere application of private company law mechanisms, the ECJ rebuffed by noting that they had not arisen "as the result of the normal operation of company law," but were instead approved by the secretary of state pursuant to the privatization statute. Case C-98/01, Comm'n v. United Kingdom, 2003 E.C.R. I-4641, at para. 48.

142. See, e.g., Case C-98/01, Comm'n v. United Kingdom, 2003 E.C.R. I-4641; Case C483/99, Comm'n v. France, 2002 E.C.R. I-4781; Case C-367/98, Comm'n v. Portugal, 2002 E.C.R. I-4731. The only golden share controversy to withstand ECJ scrutiny so far has been Case C-503/99, Comm'n v. Belgium, 2002 E.C.R. I-4809, where the Court held that "the objective pursued by the legislation at issue, namely the safeguarding of energy supplies in the event of a crisis, falls undeniably within the ambit of a legitimate public interest." Id. at para. 46.

143. See, e.g., Stefan Grundmann \& Florian Möslein, Golden Shares: State Control in Privatised Companies: Comparative Law, European Law and Policy Aspects, 2001 Eur. 
The ECJ subsequently engaged in a broader scrutiny of corporate governance arrangements in the landmark challenge against Germany's so-called Volkswagen law in Commission v. Germany. ${ }^{144}$ The Volkswagen Act of 1960, which privatized the firm, specified three charter provisions that came under attack as inconsistent with E.U. law: (i) a voting cap at $20 \%$ of total capital; (ii) a supermajority voting requirement of $80 \%$ for fundamental decisions that required $75 \%$ approval under general corporate law; and (iii) special board appointment rights to the federal government and the state of Lower Saxony. ${ }^{145}$ The court found that these provisions, combined with the $20 \%$ stake held by the state of Lower Saxony, constituted an impermissible infringement on the free movement of capital. It noted that while "the capping of voting rights is a recognised instrument of company law . . . there is a difference between a power made available to shareholders, who are free to decide whether or not they wish to use it, and a specific obligation imposed on shareholders by way of legislation." 146

Following the Volkswagen case, scholars predicted that the ECJ would next engage in all-encompassing review of domestic company law, scrapping various corporate law rules that could restrict free movement of capital. ${ }^{147}$ Despite such warnings, however, the ECJ has never attempted such a broad form of "quality control" of corporate law against integrationist objectives. As elaborated in Part III below, this is not surprising. Given the multipurpose nature of corporate law arrangements, the elimination of all structural barriers to takeovers would be incredibly disruptive to current practices and difficult to implement. The result is that the states' use of general corporate law rules for protectionist purposes has not only persisted but also intensified in recent years.

Attempts to remove structural impediments to the market for corporate control have also failed, but not for lack of trying. The main regulatory initiative in this area was the Takeover Directive, which aimed to facilitate cross-border transactions. As articulated by the European Commission, the principal purposes of the Directive were not to reduce agency costs at the firm level but to promote a single capital market and increase European competitiveness. ${ }^{148}$

BANKING \& FIN. L.J. 623 (2001) ("Potentially all provisions applicable to listed companies can be tested under European law.”).

144. Case C-112/05, Comm'n v. Germany, 2007 E.C.R. I-8995.

145. For a more detailed discussion, see Jonathan Rickford, Protectionism, Capital Freedom, and the Internal Market, in COMPANY LAW AND ECONOMIC PROTECTIONISM, supra note 6 , at 67-78.

146. Case C-112/05, Comm'n v. Germany, 2007 E.C.R. I-8995, at paras. 38, 40.

147. E.g., Wolf-Georg Ringe, Company Law and Free Movement of Capital, 69 CAMBridge L.J. 378 (2010). But see Jaron Van Bekkum, Joost Kloosterman \& Jaap Winter, Golden Shares and European Company Law: The Implications of Volkswagen, 5 EuR. COMPANY L. 6, 12 (2008) (arguing that Volkswagen does not apply to purely private arrangements).

148. Commission Proposal for a Directive of the European Parliament and of the Council on Takeover Bids, COM (2002) 534 final (Oct. 2, 2002); see Paul Davies, Edmund-Philipp Schuster \& Emilie van de Walle de Ghelcke, The Takeover Directive as a Protectionist Tool?, in COMPANy LAW AND ECONOMic Protectionism, supra note 6, at 106 n.4. 
The Commission's 1997 proposal for a Takeover Directive had gained some traction when it was surprisingly defeated in the final stage of the legislative process in 2001 after a change of heart by the German government. The backdrop of this opposition was the then recent hostile acquisition of Mannesmann by Vodafone, which instigated large German companies such as Volkswagen and BASF to lobby the government for fear that they too could fall into foreign hands. ${ }^{149}$ Germany felt that the board neutrality rule in the proposed Takeover Directive made its firms asymmetrically exposed to foreign acquisitions. ${ }^{150}$ While recent reforms had increased the contestability of control of German companies, potential targets in other jurisdictions continued to have structural protections in place. ${ }^{151}$

In response to the Directive's rejection by the European Parliament in 2001 by a margin of one vote, the Commission gathered a High Level Group of Company Law Experts to offer independent advice on the matter. The opening of the Group's report noted that "[a]n important goal of the European Union is to create an integrated capital market in the Union," and that "[t]he regulation of takeover bids is a key element of such an integrated market." 152 In order to appease concerns about the "level playing field" that had plagued the prior proposal, the Group insisted on board neutrality but proposed a so-called break-through rule, which would dismantle deviations from the one-share, one-vote standard once the bidder acquired $75 \%$ of the cash flow rights of the company. ${ }^{153}$

The new proposal by the Commission based on the Group's recommendations again encountered significant resistance. Germany continued to counter board neutrality. France and Sweden, whose companies relied heavily on voting disparities, opposed the breakthrough rule for failing to level the playing field with respect to companies that had a majority shareholder or adopted pyramidal structures.

The impasse led to a compromise that essentially made the Directive's key components nonbinding. It permitted states to opt out of both the breakthrough rule and the board neutrality rule, provided that individual companies could opt back into these rules. ${ }^{154}$ It also introduced the possibility of applying a "reciprocity" exception to the board neutrality rule, by which the rule would not apply if the acquirer were not subject to a similar regime. ${ }^{155}$ While the concept of reciprocity is a cherished one in international relations and affects popular attitudes toward foreign investment, ${ }^{156}$ its embrace by the Takeover Directive is a clear, if odd, response to economic nationalism. ${ }^{157}$

149. Skog, supra note 74, at 296.

150. See supra note 69 and accompanying text.

151. See supra note 69 and accompanying text.

152. High Level of Co. Law Experts, Report of the High Level Group of Company LAW EXPERTS ON ISSUES RELATED TO TAKEOVER BIDS 2 (2002).

153. Id. at 4 .

154. Davies et al., supra note 148 , at 107.

155. For a discussion of the interpretative uncertainties concerning the application of the exception to non-E.U. acquirers, see $i d$. at 129.

156. See infra note 331 and accompanying text.

157. Davies et al., supra note 148, at 129-30, 130 n.111. While there is considerable uncertainty about the consequences and rationale of corporate law rules, the reciprocity regime in the Directive stands out as a rule that cannot plausibly be interpreted as a response to agency 
The final version of the Takeover Directive illustrates the difficulties in overcoming the grip of nationalism on corporate law, even in a long-term, multilateral effort established for this precise purpose. In the end, by making the prohibition on takeover defenses optional, the Directive lost its teeth; it was "not worth the paper it's written on," in the words of the commissioner responsible for the proposal. ${ }^{158}$ Strikingly, most domestic legal reforms following the Directive embraced greater, rather than fewer, takeover defenses. ${ }^{159}$ More recently, growing apprehension about a Chinese buying spree has also led European countries (most notably Germany and France) to push for the adoption of E.U. legislation to monitor and restrict foreign investments through noncorporate law means. ${ }^{160}$

$$
\text { F. Japan }
$$

Japan's traditional system of corporate governance based on keiretsu networks of cross-shareholdings, bank-centered finance, and life-long employment has attracted significant scholarly attention. Japan's corporate system also stands out for being highly insulated from foreign influence. Levels of foreign direct investment (FDI) in the country are extraordinarily low and so is the incidence of foreign acquisitions. ${ }^{161}$ Remarkably, Japan is the only developed economy that has yet to witness its first successful hostile takeover in the postwar era. ${ }^{162}$

Such entrenchment of domestic control has coexisted both with a nominal lack of protectionist policies and with high levels of outward FDI by Japanese firms. In lieu of overt restrictions against foreign investors, Japan's corporate governance system did most of the work - a strategy of stealth protectionism that a scholar labeled the "privatization of economic nationalism." 163 Indeed, the Japanese system of crossshareholdings arose deliberately as a defense against foreign takeovers in the 1960s and early 1970s, when Japan opened its capital markets as a result of its accession to the OECD. ${ }^{164}$ The keiretsu system of corporate governance featured prominently in

costs.

158. Vanessa Edwards, The Directive on Takeover Bids - Not Worth the Paper It's Written On?, 1 Eur. COMPANY \& Fin. L. ReV. 416, 416-17 (2004).

159. Report on the Implementation of the Directive on Takeover Bids, at 10, SEC (2007) 268 (Feb. 21, 2007) ("The number of Member States implementing the Directive in a seemingly protectionist way is unexpectedly large."); see also Davies et al., supra note 148, at 153 .

160. European Parliament Press Release: Foreign Investment to be Screened to Protect EU Countries' Strategic Interests (May 28, 2018).

161. Dan W. Puchniak, The Efficiency of Friendliness: Japanese Corporate Governance Succeeds Again Without Hostile Takeovers, 5 BeRKELEY Bus. L.J. 195, 219 n.135 (2008).

162. Dan W. Puchniak \& Masafumi Nakahigashi, The Enigma of Hostile Takeovers in Japan: Bidder Beware, 15 BERKELEY Bus. L.J. 4, 8 (2018).

163. Christopher Pokarier, Open to Being Closed? Foreign Control and Adaptive Efficiency in Japanese Corporate Governance, in CORPORATE GOVERNANCE IN THE 21ST Century: Japan's Gradual Transformation 197, 200 (Luke Nottage et al. eds., 2008) (emphasis omitted) (describing when "an economic nationalist government pursues FDI policy liberalisation for the nation's firms abroad while building discretely exclusionary defences at home").

164. See Paul Sheard, The Economics of Interlocking Shareholding in Japan, 45 
the "Structural Impediments Initiative" (SII), a round of bilateral U.S. and Japan trade negotiations in the late 1980s that aimed at addressing the perception that most barriers against foreign investment in Japan were informal in nature. ${ }^{165}$

Even as cross-shareholdings dwindled and foreign investment rose since the banking crisis of the 1990s, as banks were forced to divest their shareholdings, ${ }^{166}$ corporate law and ownership structures have continued to serve as a powerful weapon against foreign takeovers. Cross-shareholdings remain significant in smaller firms that are most vulnerable to foreign takeovers and hedge fund activism. ${ }^{167}$ Moreover, when Japanese firms seemed exposed to foreign takeovers in the early 2000s, the Ministry of Economy, Trade and Industry (METI) gathered experts in a Corporate Value Study Group to formulate a response. "Because of an increase in the desire of foreign firms to acquire Japanese companies," government papers explained, "it is necessary to develop reasonable takeover defenses in order to cope with acquisitions that will have an adverse effect on regional employment." 168 Yet one of the four guiding principles of the Study Group was the absence of discrimination between foreign and Japanese firms, together with the enhancement of corporate value, global standards, and the expansion of choice. ${ }^{169}$

This effort resulted in the enactment of Takeover Guidelines by METI and the Ministry of Justice, which relied heavily on Delaware law to endorse and regulate the use of takeover defenses. ${ }^{170}$ The Guidelines aimed to dispel doubts about the validity of takeover defenses in Japan, sanctioning the use of protective measures that had previously been challenged by Japanese courts. ${ }^{171}$ By borrowing from Delaware law, Japan embraced global standards that were not discriminatory in nature but granted managers significant leeway to fend off foreign takeover

RICHERCHE ECONOMIQUE 421, 426 (1991) ("The prospect of capital liberalization - and the fear that it would lead to hostile takeover attempts by foreign corporations - produced a panic mentality among Japanese managements and policymakers, and triggered a concerted effort by firms to increase the proportion of their shares in stable hands."); Gen Goto, Legally "Strong”" Shareholders of Japan, 3 Mich. J. Priv. EQuity \& Venture CAP. L. 125, 153 n.168 (2014); Randall Morck \& Masao Nakamura, Banks and Corporate Control in Japan, 54 J. FIN. 319, 320 (1999).

165. Curtis J. Milhaupt, Is the U.S. Ready for FDI from China? Lessons from Japan's Experience in the 1980s, in INVESTING IN THE United StATES: A REFERENCE SERIES for Chinese InVEstors 11 (2008).

166. Goto, supra note 164 , at 145.

167. Id. at 146 .

168. Curtis J. Milhaupt, In the Shadow of Delaware? The Rise of Hostile Takeovers in Japan, 105 CoLUM. L. REV. 2171, 2182-83 n.36 (2005).

169. Id. at 2195 .

170. Id. at 2173. The significance of the Takeover Guidelines has diminished in the last decade in view of subsequent court decisions and revisions to the listing rules of the Tokyo Stock Exchange that substantially incorporate the Takeover Guidelines. Puchniak \& Nakahigashi, supra note 162, at 23 (arguing that there is great uncertainty about the scope of permissible takeover defenses in Japan).

171. See Milhaupt, supra note 168, at 2196-97. 
threats. ${ }^{172}$ The Japanese government has since explicitly encouraged the adoption of poison pills to ward off foreign acquirers. ${ }^{173}$

A broader picture of M\&A activity in Japan further highlights the import of nationalist considerations. Japan went through a major wave of consolidation through friendly M\&A transactions since the late 1990s, but foreign takeovers remained rare. ${ }^{174}$ Corporate law reforms that overtly discriminated against foreign buyers, by preventing or constraining them from using tax-favored share-for-share exchanges, played an important role in this outcome. ${ }^{175}$

Concerns about foreign ownership in Japan are understandable in view of its potential to disrupt the country's distinctive system of corporate governance. The traditional features of industrial cooperation and lifelong employment depend heavily on a loyal shareholder base embedded in Japan's homogeneous business culture. Foreign owners are more likely to lack a similar commitment to a stakeholder orientation in corporate governance. In a "clash of capitalisms," the increase in foreign investment in Japan during the 1990s was associated with greater downsizing and asset divestitures, especially in firms that lacked close ties to corporate groups and financial institutions. ${ }^{176}$

\section{G. Brazil}

The above discussion makes clear that nationalist influence on corporate law is prevalent among the highly developed jurisdictions that have been the focus of comparative corporate governance. The same phenomenon is also present in developing countries, which are especially well known for embracing economic nationalism from time to time in an effort to catch up. ${ }^{177}$ Take the example of Brazil. Nationalist objectives were paramount in the promulgation of Brazil's Corporations Law (Law 6.404) and had a clear impact on ownership structures in Brazil. State ownership, disparate voting rights, shareholder agreements, and foreign ownership restrictions are among the devices used to keep major firms in local hands, profoundly affecting the corporate governance landscape.

Enacted in 1976, policymakers overtly conceived Brazil's Corporations Law as "an essential instrument for the creation and strengthening of national private enterprise."178 Then Treasury Secretary Mário Henrique Simonsen resented the dearth of large domestic corporations under private control. Out of the twenty largest

172. Id. at 2205-06.

173. Under Pressure: Japan's Basic Industries, ECONOMIST, Sep. 7, 2006, at 65.

174. See Puchniak, supra note 161, at 222 ("While the government tried to facilitate friendly M\&A between Japanese companies, it took the opposite approach towards foreign M\&A and hostile takeovers.") (emphasis omitted).

175. Id. at 222-23.

176. Christina L. Ahmadjian \& Gregory E. Robbins, A Clash of Capitalisms: Foreign Shareholders and Corporate Restructuring in 1990s Japan, 70 AM. Soc. REV. 451 (2005).

177. Mancur Olson, Economic Nationalism and Economic Progress, 10 World ECon. 241, 241 (1987) (noting that economic nationalism is more popular in less developed countries).

178. Exposição de Motivos ao Decreto-Lei No. 196, de 24 de junho de 1976 (pelo Ministro da Fazenda) [hereinafter Exposição de Motivos]. 
Brazilian companies as of 1972 , eleven were SOEs, seven were controlled by foreign investors, and only two were controlled by Brazilian private capital. ${ }^{179}$

Economic nationalism inspired the adoption of various distinctive corporate law rules. The corporate statute qualifies the conduct of a controlling shareholder that is "harmful to the national interest" as one of the instances of "abuse of control power" resulting in controlling shareholder liability. ${ }^{180}$ According to the law's official Exposition of Motives, the statute sought to impose on managers and shareholders a "new duty of loyalty" to consider the interests of the country, a duty that applied equally to domestic and foreign firms operating in Brazil. ${ }^{181}$ The statute also includes a symbolic, though easily circumventable, prohibition on subsidiaries that are wholly owned by a foreign company, with the purpose of "making clear that the statute bans the subordination of the interests of the national company to the foreign one." 182 In addition, only Brazilian residents may serve as corporate officers and members of the fiscal board (conselho fiscal), a restriction that applied to members of the board of directors (conselho de administração) until 2001. ${ }^{183}$

Nationalist sentiment was also decisive in the embrace of state ownership in Brazil. In Brazil's underdeveloped capital markets, the prospect of private ownership of large-scale enterprise was often unavailable. Faced with the alternatives of foreign ownership and state ownership, political support gravitated toward the latter.

In 1953, the federal government incorporated Petrobras-which would later become one of the world's largest oil companies - following a strong nationalistic campaign based on the slogan "the oil is ours." 184 For most of its history, foreigners could not hold shares in Petrobras. ${ }^{185}$ While foreign ownership was eventually permitted in a 1997 reform, and Petrobras began issuing ADRs in the New York Stock Exchange in 2000, the law continues to require the government to serve as the controlling shareholder of Petrobras by holding a majority of its voting shares. ${ }^{186}$

Even during the heyday of neoliberal policies in the 1990s, which led to a wave of privatizations, concerns about national control did not disappear. Many SOEs were sold to groups of domestic (and sometimes foreign) investors bound by a shareholders' agreement. Pension funds of SOEs, as well as the equity arm of Brazil's National Development Bank (BNDES), figured prominently in these tight

179. Mário Henrique Simonsen, A Nova Economia Brasileira (1974).

180. Lei No. 6.404, de 15 de Dezembro de 1976, DiÁRIO OfiCial da União [D.O.U.] de 17.12.1976 (Braz.), art. 117, § $1^{\mathrm{o}}$, a [hereinafter Law 6.404].

181. Exposição de Motivos, supra note 178 . The document explicitly alludes to the fact that "the controlling shareholder is often a foreign company or group which is, because of its origin, excluded from the social sanctions of the community."

182. Id. The provision can be circumvented by having a foreign company own $99 \%$ or more of the stock while another company (typically belonging to the same group) holds $1 \%$ or less.

183. Law 6.404, art. 146.

184. Lei No. 2.004, de 3 de outubro de 1953, Diário Oficial da União [D.O.U.] de 3.10.1953 (Braz.) (repealed by Lei No. 9478/97).

185. Id. art. 18.

186. Lei No. 9.478, de 6 de agosto de 1997, DiÁRIO OfiCIAL DA União [D.O.U.] de 7.8.1997 (Braz.), art. 62. 
control groups bound by shareholders' agreements. ${ }^{187}$ As a result, the centrality of government players in corporate networks in Brazil increased following these privatizations. ${ }^{188}$

These ownership arrangements relied heavily on new mechanisms of corporate law. In 2001, a legal reform to the corporations law significantly strengthened the effects of shareholders' agreements, which, among other things, were allowed to bind directors' votes. ${ }^{189}$ When the government sold its crown jewels, such as mining company Vale and aircraft manufacturer Embraer, it made sure to include golden shares requiring its consent on acquisitions (as well as voting caps, in the case of Embraer) to insulate these firms from foreign takeovers. Moreover, in the 2000s, the government spent billions of dollars in ambitious equity and debt infusions to promote national champions. ${ }^{190}$ Although corruption allegations have subsequently surfaced, nationalistic industrial policies had long lent legitimacy to such hefty government support.

Similarly to other countries, the dissociation of cash flow and voting rights has also served to uphold domestic control in Brazil. In Petrobras, for instance, the use of nonvoting preferred shares permits the federal government to exercise uncontested corporate control over the company even though a majority of the shares is in the hands of private (and, these days, mostly foreign) investors. ${ }^{191}$ Yet the prevalence of foreign ownership seems to have a negative effect on prevailing attitudes toward investor protection. Despite recent instances of securities fraud associated with corruption scandals, the company is consistently portrayed as a victim, rather than a perpetrator. ${ }^{192}$ Meanwhile, commentators denounce the issuance of Petrobras ADRs on the New York Stock Exchange as "an inadmissible attack against our sovereignty," arguing that U.S. securities class actions against the company violate the Brazilian public order and should not be recognized in the country. ${ }^{193}$

\section{H. United States}

Compared to continental Europe, Asia, and developing countries, nationalist considerations have played a comparatively modest role in U.S. corporate law and

187. SÉrgio G. LaZZARini, CAPITAlismo de LaÇOS (2010).

188. Id.

189. Lei No. 10.303, de 31 de outubro de 2001, art. 118, D.O.U. de 1.11.2001 as amended.

190. Mariana Pargendler, Governing State Capitalism: The Case of Brazil, in REGULATING the Visible Hand? The Institutional Implications of Chinese State Capitalism (Benjamin L. Liebman \& Curtis J. Milhaupt eds., 2016).

191. Approximately $38.4 \%$ of Petrobras's capital (or over $57 \%$ of its free float) is held by foreign investors. Shareholding Structure, PETROBRAS INVESTOR RELATIONS, https://www.investidorpetrobras.com.br/pt/visao-geral/composicao-acionaria [https://perma.cc/JP8U-MRAK].

192. Carlos Henrique Abrão \& Érica Gorga, Samarco Ré, Petrobrás Vitima, Estado (Dec. 31, 2005, 3:00 AM), https://opiniao.estadao.com.br/noticias/geral,samarco-re--petrobrasvitima,10000005959 [https://perma.cc/Z6AU-M62P].

193. Walfrido Jorge Warde Júnior, Em Defesa da Petrobras, pelo Brasil, CARTA MAIOR: PolíticA (Feb. 16, 2005, 12:00 AM), https://www.cartamaior.com.br/?/Editoria/Politica/Emdefesa-da-petrobras-pelo-Brasil/4/32882 [https://perma.cc/K4R7-9VHL] (free translation). 
governance in recent times. ${ }^{194}$ This goes a long way in explaining the neglect of this theme in the corporate governance literature, which is still largely U.S. centric. However, even if nationalist concerns about foreign ownership of corporations have been less visible in the United States, they have still left a mark on corporate governance arrangements. This is especially significant given that the United States has historically exhibited low levels of FDI compared to both developed and developing economies. ${ }^{195}$ Moreover, analogous protectionist tendencies against outof-state parties have been a dominant force in corporate lawmaking at the state level, even if they lack the same appeal as protectionist measures bolstered by references to national identity.

When the United States was a developing economy in the nineteenth century, nationalist concerns had a visible impact on corporate governance arrangements. The charter of the First Bank of the United States, a crucial corporation in the country's early history and the government's fiscal agent, expressly disenfranchised foreign investors. ${ }^{196}$ In defending the charter provision that prohibited foreign shareholders from voting by proxy, Alexander Hamilton emphasized "the want of precautions to guard against a foreign influence insinuating itself into the Direction of the Bank." 197 He warned that "[i]t seems scarcely reconcilable [sic] with a due caution to permit, that any but citizens should be eligible as Directors of a National Bank, or that nonresident foreigners should be able to influence the appointment of Directors by the votes of their proxies." 198

Hamilton, who was otherwise a supporter of foreign capital, ${ }^{199}$ justified these measures by arguing that the Bank was "not a mere matter of private property, but a political machine of the greatest importance to the state." 200 While the proportion of its shares held abroad eventually reached over $70 \%$ of its capital, the Bank remained

194. At least until World War II, U.S. trade policy was highly protectionist. See Michael Borrus \& Judith Goldstein, United States Trade Protectionism: Institutions, Norms and Practices, Nw. J. INT'L L. \& Bus. 328, 329 (1987) (stating that in the post-war period, "[t]he United States could be committed to free trade for the same reason that Mohammed Ali in his prime time only needed a fair fight: no one could touch them").

195. Ha-Joon Chang, Regulation of Foreign Investment in Historical Perspective, 16 EuR. J. DEV'T RESEARCH 687 (2004). Most foreign capital infusions in the United States prior to World War I took the form of greenfield investments. Despite growing levels of foreign direct investment in the United States today, they are still modest compared to those of other countries. GRAHAM \& MARCHICK, infra note 249, at 27. However, foreign (and especially British) bondholdings were an important source of capital to U.S. corporations in the nineteenth century, especially railroads.

196. Alexander Hamilton had contemplated using the Bank of North America as a national bank, but its lack of charter restrictions against foreign influence helped justify the need for a new institution. Mira WiLkins, The History of Foreign InVESTMENT IN THE United STATES TO 1914, at 38 (1989).

197. Alexander Hamilton, Secretary of the Treasury, Final Version of the Report on the Subject of Manufactures, communicated to the House of Representatives (Dec. 14, 1790).

198. Id.

199. For his strong defense of foreign investment in manufacturing one year later, see Report of the Secretary of the Treasury of the United States, on the Subject of Manufactures: Presented to the House of Representatives, December 5, 1791, at 21.

200. Hamilton, supra note 197. 
entirely within U.S. control. ${ }^{201}$ Nevertheless, fears of foreign influence were a key factor behind the congressional decision not to recharter the Bank. ${ }^{202}$

When Congress established the Second Bank of the United States in 1816, it again prevented foreign shareholders from voting. ${ }^{203}$ Yet the new Bank also attracted considerable interest from foreign (mostly British) investors, and nearly a third of the Bank's stock came to be held abroad. ${ }^{204}$ The prevalence of foreign ownership was a central theme in President Andrew Jackson's refusal to renew the charter of the Bank, which was then America's largest business enterprise. ${ }^{205}$ In his veto message to the bill that sought to recharter the Bank, Jackson referred to foreign ownership and its inconveniences over twenty times. ${ }^{206}$ When the National Bank Act of 1864 created a system of federal bank chartering to finance the Civil War, nationalist considerations again reappeared in the rule limiting directorships in national banks to U.S. citizens. ${ }^{207}$

Outside of the banking sector, foreign ownership was less conspicuous in the early part of the nineteenth century, but there were still nationalist responses. ${ }^{208}$ The protectionist instincts that polities show against nonmembers played out primarily at the state level. This tension is visible in the numerous controversies concerning what constituted permissible state law discrimination against the so-called foreign corporation - here understood as a corporation chartered not by another country, but by another state.

Through the early nineteenth century, the creation of business corporations required special charters by the legislature, which were premised on the promotion of a local improvement and typically entailed monopoly privileges. ${ }^{209}$ These early corporations were territorial institutions, established in the state of residence of their founders and conducting most, if not all, of their business within the state. ${ }^{210}$ Some charters specifically required directors and officers to be state residents, and shareholder and board meetings to be held in the state. ${ }^{211}$

More fundamentally, the prevailing legal doctrine at the time was that, as an artificial creature of the state, a business corporation existed only within the

201. WILKINS, supra note 196, at 61.

202. Id.

203. Id.

204. President Andrew Jackson, Veto Message Regarding the Bank of the United States (July 10, 1832) (transcript available in the Yale Law School Library) ("Already is almost a third of the stock in foreign hands and not represented in elections.").

205. WILKINS, supra note 196, at 62.

206. Jackson, supra note 204 ("If we must have a bank with private stockholders, every consideration of sound policy and every impulse of American feeling admonishes that it should be purely American. Its stockholders should be composed exclusively of our own citizens, who at least ought to be friendly to our Government and willing to support it in times of difficulty and danger.").

207. WILKINS, supra note 196, at 583.

208. Chang, supra note 195, at 691.

209. Henry N. Butler, Nineteenth-Century Jurisdictional Competition in the Granting of Corporate Privileges, 14 J. LEGAL STUD. 129, 138 (1985).

210. Frederick Tung, Before Competition: Origins of the Internal Affairs Doctrine, $32 \mathrm{~J}$. CORP. L. 33, 56 (2006).

211. Id. at 56-57. 
incorporating sovereign's territorial boundaries. ${ }^{212}$ Special charters granted by the state legislature typically banned corporations from operating outside of the territory. This rule also carried over to many general incorporation statutes that aimed to liberalize the incorporation process by eliminating the need for a special legislative charter. ${ }^{213}$ The right to operate out of state remained a privilege granted only by some special charters, which made it relatively rare. ${ }^{214}$ Until the Supreme Court's commerce clause jurisprudence of the 1860 s, states systematically discriminated against foreign corporations in tax and regulatory matters. ${ }^{215}$

The emergence of the internal affairs rule in the U.S. federalist system - a key component of the "genius" of American corporate law ${ }^{216}$ — was mostly an accident of history, not the result of a deliberate policy to promote regulatory competition or to curb agency costs. ${ }^{217}$ The internal affairs rule provides that the law of the state of incorporation governs the relationships among the corporation, its managers, and its shareholders. The early decisions articulating the doctrine in the 1860s contained a jurisdictional rule, according to which only the courts of the incorporating state had the power to address matters of internal affairs. ${ }^{218}$ Crucially, the doctrine emerged at a time where territorial ties to the chartering state prevailed, and firms had limited choice about where to incorporate. ${ }^{219}$

This timing explains the lack of protectionist pressures against the internal affairs rule. Given the constraints on corporate mobility prevailing at the time of the rule's initial articulation, even protectionist U.S. states had no reason to safeguard the application of their own corporate laws within their territory through a conflicts rule. ${ }^{220}$ This scenario stands in sharp contrast to the emergence of the real seat doctrine in Europe, which developed to restrain the cross-border mobility of corporations then well underway. ${ }^{221}$ Regulatory competition began in earnest with New Jersey's active strategy to attract incorporations from out of state in the late nineteenth century by offering liberal charters to foreign firms irrespective of a requirement or expectation of state presence. ${ }^{222}$

The success of regulatory competition for corporate charters in the United States is also a function of the constitutional constraints imposed on states' protectionist tendencies. This is a critical, but often neglected, component of the U.S. institutional landscape. Some courts have gone so far as to suggest that the internal affairs doctrine

212. Bank of Augusta v. Earle, 38 U.S. 519, 588 (1839) ("It is very true that a corporation can have no legal existence out of the boundaries of the sovereignty by which it is created.").

213. Tung, supra note 210 , at 62 .

214. Id.

215. Id. at 58-60.

216. Roberta Romano, The Genius of American Corporate Law (1993).

217. Tung, supra note 210 , at 33 (contending that "the doctrine's origin had nothing to do with regulatory competition").

218. Id. at 66 .

219. Id. at 37 .

220. Richard Buxbaum, The Origins of the American 'Internal Affairs' Rule in the Corporate Conflict of Laws, in FeSTSChrift Für Gerhard Kegel ZUM 75. GeburtSTAG 26 JUNI 1987, at 84 (Hans-Joachim Musielak \& Klaus Schurig eds., 1987).

221. Id. at 85 .

222. Tung, supra note 210 , at $38,45,57$. 
is mandated by the U.S. Constitution. ${ }^{223}$ While there is scholarly support to this view, ${ }^{224}$ other commentators have questioned the constitutional stature of the internal affairs doctrine, not least because internal affairs are never purely "internal.",225

Nevertheless, the Constitution's commitment to economic integration has limited the states' ability to discriminate against out-of-state firms, with significant consequences for corporate law. The U.S. Supreme Court's 1869 decision in Paul v. Virginia ${ }^{226}$ effectively spurred the market for corporate charters. ${ }^{227}$ As discussed above, the status of foreign corporations was highly uncertain until then. ${ }^{228}$ Although Paul formally held that a state could lawfully exclude a foreign corporation that was not deemed to engage in interstate commerce, its "corollary" was that "a state had no power to exclude a corporation from doing interstate business." 229 This effectively permitted foreign corporations doing interstate business, which are those most vulnerable to protectionist behavior by host states, to shop for corporate charters at their convenience.

However, the rise of regulatory competition did not eliminate the states' protectionist instincts or their legal ability to restrict the powers of foreign corporations. Although the Supreme Court had limited the states' ability to discriminate against out-of-state agents or prevent interstate commerce, it did not prevent states from excluding foreign corporations from carrying out other forms of business within the state. ${ }^{230}$ States typically required local chartering of regulated industries such as banking, insurance, and utility companies. ${ }^{231}$

Nevertheless, even as states placed various restrictions on foreign corporations, they typically lacked similar constraints on foreign shareholders, arguably because

223. E.g., Draper v. Gardner Defined Plan Trust, 625 A.2d 859, 867 (Del. 1993) (suggesting "the vitality and constitutional underpinnings of the internal affairs doctrine"); McDermott v. Lewis, 531 A.2d 206, 216 (Del. 1987) (stating that "application of the internal affairs doctrine is mandated by constitutional principles"); see also Edgar v. MITE Corp., 457 U.S. 624, 645-46 (1982) ("Illinois has no interest in regulating the internal affairs of foreign corporations.").

224. See, e.g., Henry N. Butler \& Larry E. Ribstein, The Corporation and the COnstitution, at xi (1995) (suggesting that the internal affairs doctrine is a corollary of the Commerce Clause, "which can be interpreted as protecting the parties from state legislation that benefits locals at the expense of nonresidents").

225. See, e.g., Jed Rubenfeld, State Takeover Legislation and the Commerce Clause: The "Foreign" Corporations Problem, 36 CLEV. ST. L. REV. 355, 380-82 (1988).

226. 75 U.S. 168 (1869).

227. Butler, supra note 209, at 136.

228. See supra notes $212-215$ and accompanying text.

229. Harry G. Henn, Handbook of the Law of Corporations And Other Business ENTERPRISES 19 (1970); Butler, supra note 209, at 155 ("The impact of Paul v. Virginia on the legislative market for corporate privileges was enormous.").

230. Herbert Hovenkamp, Antitrust Policy, Federalism, and the Theory of the Firm: An Historical Perspective, 59 AnTITRUST L.J. 75, 85 (1990).

231. See Ronald J. Gilson, Henry Hansmann \& Mariana Pargendler, Regulatory Dualism as a Development Strategy: Corporate Reform in Brazil, the United States, and the European Union, 63 STAN. L. REV. 475, 519-20 (2011) (contrasting the system of state chartering of banks to the system of liberal choice of law applicable to industrial corporations). 
they were so rare. ${ }^{232}$ This asymmetric treatment allowed entrepreneurs to take advantage of a new organizational form, the holding company, to create multistate businesses while complying with state chartering requirements. Under this structure, the operating corporation remained local for regulatory purposes; only the shareholder (the holding company) was foreign. ${ }^{233}$

The holding company also facilitated the emergence of pyramidal ownership structures - a mechanism by which company A holds the majority of voting shares in company B, which holds the majority of voting shares in company $\mathrm{C}$, and so on. Corporate pyramids permit the concentration of corporate control in the hands of shareholders having a modest economic interest in the firm. Pyramidal structures were particularly common among U.S. utility companies through the early twentieth century, though a combination of populist-inspired tax and regulatory reforms in the 1930s dismantled them. ${ }^{234}$

Corporate governance scholars are aware of the decline of pyramidal structures in the United States today (even as they remain prevalent in other countries), ${ }^{235}$ but their origins are less appreciated. While multiple factors played a part, observers at the time highlighted the role of regulatory restrictions against foreign corporations, which pyramidal structures then helped evade. ${ }^{236}$ In his best-selling book Main Street and Wall Street, William Ripley largely absolved management for the creation of utility pyramids. "Utility managements," he argued, "are less to blame for this overextended situation than are the people of the United States," as "many states require that public utilities be conducted by domestic corporations; else they may be denied the enjoyment of such rights such as that of eminent domain." 237

The newfound circumvention of restrictions against foreign corporations, combined with the rise of charter competition with New Jersey and then Delaware leading the ranks, significantly mitigated the effects of state protectionism on corporate law. Yet protectionist considerations also played a role in the enactment of the so-called "blue sky" laws, the state-level regulations aimed at curbing fraudulent issuances of securities through disclosure mandates and administrative review of merit. Blue sky laws were arguably the most important state effort at corporate regulation until the takeover boom of the 1980s, inspiring the adoption of federal securities regulation in the 1930s. ${ }^{238}$

232. Hovenkamp, supra note 230 , at 86 .

233. Id. at 85 .

234. See RoE, supra note 11, at 107-08; Steven A. Bank \& Brian R. Cheffins, The Corporate Pyramid Fable, 84 Bus. Hist. REV. 435, 438, 442 (2010) (arguing that pyramids were important only in the utilities sector, with the Public Utility Holding Company Act of 1935 being responsible for their demise); Randall Morck \& Bernard Yeung, Dividend Taxation and Corporate Governance, 19 J. ECON. PERSP. 163, 176 (2005).

235. Enriques et al., supra note 72 , at 82 .

236. James C. Bonbright \& Gardiner C. Means, The Holding Company: Its Public SigNifiCANCE AND REGULATION 33 (1932) (attributing the creation of holding companies as a response to the legal obstacle "created by the desire of various states to keep the ownerships of various types of enterprise under a domestic corporation").

237. William Z. Ripley, Main Street And Wall Street 296 (1927).

238. Jonathan R. Macey \& Geoffrey P. Miller, Origin of the Blue Sky Laws, 70 Tex. L. REV. 347, 348 (1991). 
Whether blue sky laws were a public-spirited response to the proliferation of securities fraud or the artful product of interest group pressure remains the object of debate. In any case, it is clear that protectionist dynamics contributed to their adoption. Legal reforms to protect outside investors are generally hard to come by in the absence of a major scandal or crisis, since investors are a dispersed group that face significant collective action problems compared to managers and controlling shareholders. ${ }^{239}$ However, the lopsided nature of the protection afforded by blue sky laws mitigated this problem: only in-state investors benefited from regulatory protection under blue sky laws, while corporate promoters were often based out of state. ${ }^{240}$

In contrast to the conventional view that blue sky laws sought to protect investors, Jonathan Macey and Geoffrey Miller have argued that special interests played a significant part in their enactment. ${ }^{241}$ Small banks and local borrowers stood to benefit from blue sky legislation as a means of reducing competition for funds from out-of-state securities firms during a period of credit scarcity. ${ }^{242}$ Protectionism was an explicit motivation behind the pioneering blue sky legislation from the state of Kansas. Regulatory entrepreneur J.N. Dolley, who was instrumental in the passage of the act, explicitly pointed to the millions of dollars being "taken from Kansas" to out-of-state firms. ${ }^{243}$

While U.S. states were also highly protectionist of local champions and their headquarters, as will be examined further below, they were less interested in generally promoting American nationalism against non-U.S. capital. ${ }^{244}$ The result is that policies towards promoting or maintaining U.S. ownership were primarily championed by the federal government. Because corporate law in the United States had become a matter of state law, the United States appears to have relied more than other countries on administrative law, rather than corporate governance mechanisms, to protect its national industry.

It is revealing, however, that the enactment of the Williams Act of 1968 - the only piece of U.S. federal legislation targeting hostile takeovers to date- had the foreign takeover threat against Columbia Motion Pictures as its poster child for the perils of unregulated acquisition markets. Although Senator Williams first proposed legislation aimed at deterring tender offers in 1965, the version of the bill that was eventually enacted was cosponsored by Senator Kuchel of California, who became an ardent critic of the tender offer regime when Columbia Motion Pictures faced a

239. For an examination of the political hurdles to the enactment of investor protection reforms, see Gilson et al., supra note 231 .

240. Macey \& Miller, supra note 238, at 349, 352 (the first and most stringent adopters of blue sky legislation were agricultural states that lacked a robust securities industry).

241. Id.

242. Id. at 350 .

243. Id. at 369 (" $[\mathrm{M}]$ oney . . . was being taken by the promoter from our State to the headquarters of his company, a large [percent] of it going to New York and the East.") (quoting J.N. Dolley, Blue Sky Law, 77 Am. BANKeR 1705, 1705 (1912)).

244. See, e.g., Milhaupt, supra note 165 (noting that state governments were far more welcoming to Japanese FDI than the federal government in the 1980s). There are, however, various exceptions to this trend, such as the New York laws discriminating against non-U.S firms operating in the financial sector. WILKINS, supra note 196, at 579-80. 
tender offer from the Banque de Paris et de Pays Bas. ${ }^{245}$ In his 1966 letter to the Securities and Exchange Commission (which was attached to the bill), Kuchel emphasized the importance of Columbia to the California economy and warned that "[t]his power of life or death over any American business or industry, directly or indirectly in the hands of a foreign group, is patently against the national interest." ${ }^{246}$ $\mathrm{He}$ also specifically mentioned the Columbia incident to argue that the existing securities regime "opens up the possibilities of all kinds of foreign interests coming in here and participating in attempts to control various communications media."247

While the reference to foreign takeover threats is useful in garnering political support, Columbia never faced a real risk of falling under French control. The reason for the takeover's failure at that time, as well as in the past, lay in foreign ownership restrictions long enshrined in federal law. The Communications Act of 1934 prohibited foreign shareholders from owning more than one-fifth of a U.S. company with broadcasting holdings, a restriction that applied to Columbia as an indirect owner of TV stations. ${ }^{248}$ The Communications Act was only one of various industryspecific restrictions on foreign ownership and control enacted after World War I, which also encompassed marine shipping, aircraft manufacturing, and the oil industry. ${ }^{249}$ Apart from banking, security concerns ostensibly drove these restrictions, even though FDI played a comparatively modest role in the U.S. economy. ${ }^{250}$

Prior to the enactment of formal legislation preventing foreign control of radio and telecommunications, the pursuit of domestic control developed informally, such as when General Electric forced the American Marconi, which was then under British control, to sell its radio patents at the encouragement of the U.S. Navy in 1919. ${ }^{251}$ The purchase and subsequent transfer of these assets to the newly created Radio Corporation of America (RCA) served the Navy's objectives of ensuring domestic

245. 113 CON. REC. S858 (1967) (arguing that the takeover attempt had "far-reaching implications for the economic welfare of the State of California and the Nation").

246. Id. at 858 (citing Columbia's payroll, gross receipts and thousands of workers, and arguing that "[a]ny potential threat to [Columbia's] existence is, of course, an equal threat to its California based personnel, and to the myriad of related firms who do business with Columbia").

247. Full Disclosure of Corporate Equity Ownership and in Corporate Takeover Bids: Hearings on S. 510 Before the Subcomm. on Sec. of the Comm. on Banking and Currency, 90th Cong. 44 (1967) (statement of Sen. Kuchel).

248. Born-Again Columbia Pictures, WAsh. Post (Jan. 15, 1978), https://www.washingtonpost.com/archive/politics/1978/01/15/born-again-columbia-pictures /79318b88-f999-4be7-918b-8abc96441f3d/ [https://perma.cc/L7PF-54P6] (describing the frustrated takeover attempt by the Banque de Paris et des Pays Bas in 1936); Columbia TriStar

Motion Pictures Companies History, FundINGUnIVERSE, http://www.fundinguniverse.com /company-histories/columbia-tristar-motion-pictures-companies-history/ [https://perma.cc/EN2T-T783] (describing the 1936 and the 1966 takeover attempts).

249. Edward M. Graham \& David M. Marchick, U.S. National Security and FOREIGN DiRECT INVESTMENT 11-13 (2006).

250. Id. at 9 ("US direct investment abroad in 1930 was almost six times greater than FDI in the United States.").

251. Id. at 10 (describing the seizure of broadcasting assets of Marconi in 1912 and the subsequent sale of radio patents to GE under threat of Congressional Action). 
control of the radio industry without having to undertake control themselves. ${ }^{252}$ The RCA's charter prevented foreigners from holding more than 20 percent of the stock and serving as directors or officers, and granted a government representative "the right of discussion and presentation in the board of the Government's views and interests concerning matters coming before the board." ${ }^{253}$ This type of private domestic alternative to foreign ownership is one of the reasons why the United States successfully resisted the appeal of state ownership during the twentieth century. ${ }^{254}$

Since the 1970s, the primary mode of response to foreign threats has taken the form of federal executive review of foreign direct investments in view of national security concerns. ${ }^{255}$ In response to the increased vulnerability of U.S. firms due to the depreciation of the U.S. dollar, President Ford established the Committee on Foreign Investments in the United States (CFIUS) in 1975, which was in charge of monitoring the impact of foreign investment, but lacked the authority to block acquisitions. ${ }^{256}$ In the 1980 s, mounting anxiety about Japanese acquisitions of U.S. firms - which peaked after Fujitsu's proposed acquisition of Fairchild, a semiconductor manufacturer-led Congress to enact the Exon Florio Amendment to the Defense Production Act of 1950. Exon Florio authorizes the President to block acquisitions that threaten "national security." ${ }^{257}$ In 1992, following the failed attempt by a French SOE to acquire a defense contractor, Congress enacted a new amendment mandating CFIUS to undertake a mandatory investigation when the acquirer in a transaction that could affect national security is "controlled by or acting on behalf of a foreign government." 258

In the 2000s, public outcry and political pressure derailed major foreign acquisitions through informal means due to national security concerns. ${ }^{259}$ In view of these incidents and the growing appetite of foreign SOEs and sovereign wealth funds for U.S. companies, Congress enacted the Foreign Investment and National Security

252. Id.

253. Erik Barnouw, A History of Broadcasting In the United States 59 (1966)

254. To be sure, the United States also temporarily nationalized enemy corporations during wartime. See Stacey R. Kole \& J. Harold Mulherin, The Government as a Shareholder: A Case from the United States, 40 J.L. \& ECON. 1, 1 (1997).

255. For a more detailed description and assessment of the evolving regulatory framework, see Alan P. LARSON \& DAVID M. MARCHICK, ForEign InVESTMENT AND NATIONAL SECURity: Getting the Balance Right (2006); George Stephanov Georgiev, The Reformed CFIUS Regulatory Framework: Mediating Between Continued Openness to Foreign Investment and National Security, 25 YALE J. ON REG. 125 (2008).

256. The Committee on Foreign Investment in the United States (CFIUS), US DEP'T OF THE TREASURY, https://home.treasury.gov/policy-issues/international/the-committee-on-foreigninvestment-in-the-united-states-cfius [https://perma.cc/5RA7-CV9J].

257. Omnibus Trade and Competitiveness Act of 1988, Pub. L. No. 100-418, § 5021, 102 Stat. 107, 1425 (codified as amended at 50 U.S.C. app. $\S \S 2158-70$ (2000)).

258. National Defense Authorization Act for Fiscal Year 1993, Pub. L. No. 102-484, § 837, 106 Stat. 2315, 2463-65 (1992) (codified at 50 U.S.C. app. § 2170(b) (2000)).

259. In 2005, the China National Offshore Oil Corporation (CNOOC), a state-owned firm, launched a bid for oil giant Unocal, but subsequently withdrew its offer following significant opposition to the transaction. In 2006, state-owned Dubai Ports World acquired P\&O, a U.K. company operating U.S. ports, but was ultimately compelled to divest following Congressional opposition. 
Act of 2007, strengthening the process of CFIUS review and imposing reporting obligations to Congress. ${ }^{260}$ This change greatly increased the number of CFIUS investigations and appears to have deterred foreign takeovers. ${ }^{261}$ The recently enacted Foreign Investment Risk Review Modernization Act of 2018 (FIRRMA) significantly expands the scope of review of foreign investment in the United States by requiring CFIUS to vet, among other things, noncontrolling foreign investment in companies that deal in critical technology, critical infrastructure, or personal data of U.S. citizens. ${ }^{262}$

In summary, the United States has not been immune to nationalist hostility towards foreign ownership. ${ }^{263}$ Although levels of FDI have been historically low in the United States, most concerns about foreign presence have been met with foreign ownership restrictions and administrative review of foreign investments by the federal government as opposed to corporate law. There is new evidence, however, that the federal government strongly intervenes in the corporate governance structure of foreign-owned defense contractors to safeguard national security. ${ }^{264}$

Meanwhile, states as corporate lawmakers were strongly statist in their reaction to the hostile takeover wave of the 1980s. Since Delaware overtook New Jersey as the most popular state of incorporation, U.S. companies have traditionally incorporated either in their home state or in Delaware. ${ }^{265}$ This means that, for nonDelaware targets, hostile bids typically pitted the interests of out-of-state bidders and public shareholders, on the one hand, against those of local managers and workers, on the other. In view of the political deficit of noncitizens and the powerful political alliance between elite and labor interests, it is no surprise that state legislatures typically favored the latter.

260. Foreign Investment and National Security Act of 2007, Pub. L. No. 110-49, 121 Stat. 246 (50 U.S.C. app. § 2061).

261. David Godsell, Does the Threat of Takeover Discipline Managers? New Evidence from the Foreign Investment and National Security Act 2-3 (unpublished manuscript) (2018), https://www.fox.temple.edu/wp-content/uploads/2018/01/Godsell-David-Does-the-Threatof-Takeover-Discipline-Managers.pdf [https://perma.cc/PTF2-LULY].

262. H.R. Rep. No. 115-784, pt. 1 (2018).

263. LARSON \& MARCHICK, supra note 255, at 3 (according to a poll by the Pew Research Center for the People and the Press, as of the mid-2000s, 53\% of Americans believed that foreign ownership of U.S. companies is "bad for America").

264. Andrew Verstein, The Corporate Governance of National Security, 95 WASH. U. L. REV. 775, 787-88 (2018) (describing the heavy reliance on government-appointed directors, among other mechanisms, in contractors that are subject to foreign ownership, control, or influence). There is no statutory basis for this special regime, which is contractual in nature. Id. at $792-93$.

265. Lucian Arye Bebchuk \& Alma Cohen, Firms' Decisions Where to Incorporate, 46 J.L. \& ECON. 383, 386 (2003); Robert Daines, The Incorporation Choices of IPO Firms, 77 N.Y.U. L. REV. 1559, 1572 (2002) (finding that nearly 95\% of firms chartered outside of their home are incorporated in Delaware); see Ofer Eldar \& Lorenzo Magnolfi, Regulatory Competition and the Market for Corporate Law, _ AM. ECONS. J: MACROECONOMICS (forthcoming 2020), https://ssrn.com/abstract=2685969 [https://perma.cc/HH8Q-9YLE] (finding that most firms continue to incorporate either in Delaware or in their home state, though Nevada has acquired a sizeable market share of out-of-state incorporations). 
These are the same forces that prodded the enactment of protective legislation in most countries where hostile takeover threats frequently come from abroad. Their presence in the U.S. federal system, but absence in the United Kingdom's centralized system of government, also helps explain why these two Anglo-Saxon and financially developed jurisdictions took opposite approaches to the regulation of hostile takeovers. ${ }^{266}$ Even the most passionate advocates of regulatory competition have pointed to its shortcomings in the U.S. takeover context. ${ }^{267}$

Indeed, the most common scenario prompting state antitakeover legislation was a feared or ongoing acquisition attempt of a major local company by an out-of-state firm. ${ }^{268}$ Connecticut enacted its antitakeover statute at the request of the Aetna Life and Casualty Insurance Company; Minnesota did the same at the request of Dayton Hudson, and the list goes on. ${ }^{269}$ Massachusetts, in turn, reformed its corporate laws in an emergency session to impose staggered boards on all firms chartered in the state in response to the takeover attempt of Massachusetts-based Norton Company by BTR, a British firm. ${ }^{270}$ The campaign against the Norton takeover-which mobilized managers, workers, and politicians - dramatically played the nationalist card by comparing BTR's tender with the British invasion of America during the Revolutionary War and equating it with "another attempt by a foreign power to interfere with our ability to shape our own [destiny]."271

State antitakeover statutes impose externalities on other states: ${ }^{272}$ they produce concentrated local benefits in the form of continued employment, while its efficiency costs are diffuse and disproportionately borne by out-of-state bidders and shareholders. This helps explain why states have been far more enthusiastic about antitakeover legislation than the federal government. ${ }^{273}$ Federal lawmakers faced a different scenario, as the majority of bidders during the takeover wave of the 1980s were U.S. rather than foreign firms. ${ }^{274}$ Even so, there were various federal takeover

266. See Armour \& Skeel, supra note 104, at 1730 (attributing the wedge in regulatory outcomes to the identity of the lawmaker in the United Kingdom, as the self-regulatory efforts of the Takeover Panel catered primarily to the interests of investment bankers and institutional investors).

267. Roberta Romano, The Political Economy of Takeover Statutes, 73 VA. L. REv. 111, 189 (1987) (claiming that, from the perspective of state antitakeover statutes, the "regulation of corporations at the state level is not an unmitigated good").

268. See Mark J. Roe, Takeover Politics, in The Deal Decade: What Takeovers And Leveraged Buyouts Mean for Corporate Governance 321, 338-39 (Margaret M. Blair ed., 1993); id., at 111, 123, 136-37; Henry N. Butler, Corporation-Specific Antitakeover Statutes and the Market for Corporate Charters, 1988 WIS. L. REV. 365 (1988).

269. See Butler, supra note 268, at 375; Romano, supra note 267, at 123.

270. Robert Daines, Shelley Xin Li \& Charles C.Y. Wang, Can Staggered Boards Increase Value? Evidence from the Massachusetts Natural Experiment 13 (Harvard Bus. Sch., Working Paper No. 16-105, 2018).

271. Id. at 11 (citing Governor Michael Dukakis).

272. Romano, supra note 267, at 140; J. Gregory Sidak \& Susan E. Woodward, Corporate Takeovers, the Commerce Clause, and the Efficient Anonymity of Shareholders, 84 Nw. U. L. REV. 1092, 1093 (1990).

273. Roe, supra note 268, at 332.

274. U.S. Gen. Accounting OfFice, Foreign Investment: Foreign Hostile TaKeovers OF U.S. FIRMS (1988) (reporting that only 17 out of 77 hostile takeovers, and 25 out of 191 
bills aimed specifically at acquisitions by foreigners, ${ }^{275}$ which were usually proposed with the goal of frustrating an ongoing hostile takeover attempt. ${ }^{276}$

U.S. constitutional law also played an important role in moderating the states' protectionist tendencies in this area. When the takeover boom in the 1980s prompted a flood of protectionist legislation by several states, the Supreme Court intervened. In Edgar v. MITE, ${ }^{277}$ the Supreme Court invalidated the Illinois exemplar of the first generation of state takeover laws. The statute in question required advance filing and administrative review prior to the launch of a tender offer and had broad jurisdictional reach. ${ }^{278}$ It covered not only corporations chartered in Illinois, but also foreign corporations that had ten Illinois shareholders or their principal office in Illinois. ${ }^{279}$ Noting that "the Illinois law on its face would apply even if not a single one of Chicago Rivet's shareholders were a resident of Illinois," Justice White's opinion for the Court found that the law imposed an excessive burden on interstate commerce. $^{280}$

Undeterred by this first blow, states quickly passed a second generation of statutes designed to withstand constitutional scrutiny. While the states deployed different rules to deter hostile takeovers, the second generation of antitakeover legislation relied on mechanisms of corporate law (as opposed to administrative review) and applied only to corporations chartered in the state. ${ }^{281}$ They therefore epitomized the use of corporate law to promote stealth protectionism. In blessing Indiana's control share acquisition statute in CTS Corp. v. Dynamics Corp. of America, the U.S. Supreme Court found the fact that the statute would apply most often to out-of-state bidders as insufficient to render it discriminatory to interstate commerce. ${ }^{282}$ The Court seemed particularly impressed by the fact that the statute looked like "a generic provision of state corporate law that regulated the voting rights of shareholders." ${ }^{283}$ While the Court permitted Indiana to enact legislation that was protectionist in intention and effect (even if not facially so), it highlighted the role of the internal affairs rule in promoting capital markets and economic integration. ${ }^{284}$

hostile takeover attempts, between 1984 and 1988 were foreign).

275. Romano, supra note 216, at 79.

276. Roberta Romano, The Future of Hostile Takeovers: Legislation and Public Opinion, 57 U. CINN. L. REV. 457, 470 n.35 (1988) (“[T]hese bills may be motivated by xenophobic sentiment unrelated to efforts at regulating takeovers, because they are most often introduced to stop a hostile takeover in progress.").

277. 457 U.S. 624 (1982).

278. Id. at 624 .

279. Id.

280. Id. at 642 .

281. Romano, supra note 267 , at $115-17$.

282. 481 U.S. 69, 88-89 (1987) ("Because nothing in the Indiana Act imposes a greater burden on out-of-state offerors than it does on similarly situated Indiana offerors, we reject the contention that the Act discriminates against interstate commerce.").

283. Jonathan R. Macey, State and Federal Regulation of Corporate Takeovers: A View from the Demand Side, 69 WASH. U. L.Q. 383, 405 (1991).

284. CTS Corp., 481 U.S. at 90. But see Sidak \& Woodward, supra note 272, at 1107 for a critique of the decision arguing that the Indiana statute violated the dormant Commerce Clause by costing nonresident shareholders more than it benefits Indiana interests. 
Since CTS, states have enacted third-generation statutes restricting business combinations, validating takeover defenses such as poison pills, and permitting directors to consider the interests of a broad set of constituencies. Curiously, several state constituency statutes specifically permit directors to consider "the economy of the state and Nation" in addition to the interests of employees, customers, the community, and the like. ${ }^{285}$ States have also strived to maintain local control of major companies in other ways, as illustrated by the extraordinary protectionist measures undertaken by the state of Pennsylvania to prevent the Hershey charitable trust from selling its controlling interest in the Hershey Company. ${ }^{286}$

Delaware, the apparent winner of the state competition for corporate charters in the United States, is not subject to the same protectionist pressures as other states. Hosting a larger proportion of potential bidders than other states, ${ }^{287}$ but virtually no workers, managers, or shareholders of target companies, Delaware embraced antitakeover laws only later and in more restrictive fashion than other states. This means that Delaware supplies market-oriented corporate law that is driven by the state's desire to attract incorporations and maximize the revenue it obtains with franchise fees. Contrast this with other states that generally offer politics-oriented corporate law that is shaped by the interests of its local constituencies and therefore shows a strong protectionist orientation. ${ }^{288}$

Although the merits of takeover defenses are hotly contested, most scholars believe that Delaware's takeover jurisprudence is more managerialist than socially optimal, ${ }^{289}$ and — what is significant for our purposes - at least partially the product of competitive pressures originating from the protectionist laws offered by other states. ${ }^{290}$ Ironically, other jurisdictions, such as Japan, have since embraced the protectionist elements of Delaware corporate law to pursue their own nationalist objectives. $^{291}$

Overall, U.S. corporate law is what it is because of a deep constitutional commitment to economic integration mitigating the states' protectionist impulses,

285. For example, the antitakeover statutes of Kentucky, Minnesota, Nevada, Ohio, and Wyoming. Admittedly, given the ample availability of the poison pill, the practical relevance of state antitakeover statutes is now the object of debate. See Emiliano M. Catan \& Marcel Kahan, The Law and Finance of Antitakeover Statutes, 68 STAN. L. REV. 629, 629 (2016).

286. See Jonathan Klick \& Robert H. Sitkoff, Agency Costs, Charitable Trusts, and Corporate Control: Evidence from Hershey's Kiss-Off, 108 CoLuM. L. REv. 749, 768 (2008).

287. Romano, supra note 276, at 468.

288. See Ronald J. Gilson, Henry Hansmann \& Mariana Pargendler, Corporate Chartering and Federalism: A New View 15-16 (2015) (unpublished manuscript), https://ecgi.global/sites /default/files/video_related/paper-hansmann.pdf [https://perma.cc/VEW7-4VEP]. For a detailed analysis of the incentives of corporate lawmakers in Delaware, see Roberta Romano, The Market for Corporate Law Redux, in 2 OXFORD HANDBOOK OF LAW AND ECONOMICS 358 (Francesco Parisi ed., 2017).

289. See, e.g., Bernard Black \& Reinier Kraakman, Delaware's Takeover Law: The Uncertain Search for Hidden Value, 96 Nw. U. L. REV. 521, 565-66 (2002).

290. Marcel Kahan \& Ehud Kamar, The Myth of State Competition in Corporate Law, 55 STAN. L. REV. 679, 740 (2002); Roe, supra note 268, at 351 (referring to Hotelling's model of competition, according to which a competitor has an incentive to position herself close to the most significant competitor to take the competitive space on the other side).

291. See supra note 172 and accompanying text. 
which nevertheless have left a clear mark on corporate law. The constitutional commitment to economic integration also guaranteed that U.S. firms faced stronger competition in product and service markets at home and thereby achieved greater productivity than their foreign counterparts. ${ }^{292}$ The economic power of U.S. multinationals, in turn, was historically an important force behind nationalist responses in other jurisdictions, though China has recently replaced the United States as the most feared foreign acquirer prompting the adoption of protectionist policies.

\section{THE ECONOMIC EFFECTS OF CONTROL NATIONALISM}

As we saw in Part I, governments around the world have assiduously pursued nationalist policies through corporate governance arrangements, but are these efforts justified? There is a large body of literature on the economic effects of nationalist policies, especially with respect to international trade. The conventional view among economists, dating back to Adam Smith and David Ricardo, is that protectionist barriers to trade not only reduce global wealth but also impoverish the jurisdiction imposing protectionist restrictions. Under this view, jurisdictions will benefit even if they open their borders unilaterally, though reciprocity can be useful as a bargaining tool to obtain greater concessions from other jurisdictions and augment the scope and the gains from free trade. ${ }^{293}$ From an international perspective, another time-honored argument is that international trade promotes peace. ${ }^{294}$

While this view continues to have supporters, some important qualifications have since emerged. First, there is a case for protecting "infant industries" in developing countries so that they stand a chance to compete against their well-established counterparts abroad. ${ }^{295}$ Second, there is also a case for strategic trade policy, as when government policy affects the terms of oligopolistic competition to transfer the

292. See, e.g., McKinsey Global Institute, Service Sector Productivity (1992) (attributing higher productivity levels in the United States to greater competition in the domestic market); Olson, supra note 177, at 243 (arguing that the "mileage of trade barriers is more important than their height," so that large economies such as the United States are less affected by protectionist policies).

293. As put by British economist Joan Robinson, "if others throw rocks into their harbor, that is no reason to throw rocks into your own." JaGDish BHAGWATI, GoING AlOnE: The CASE FOR RELAXED RECIPROCITY IN FREEING TRADE 101 (2002).

294. See, e.g., Baron de Montesquieu, The Spirit of the Laws 316 (Hafner Pub. Co. 1966). For a review of the empirical literature, see Solomon W. Polachek \& Carlos Seiglie, Trade, Peace and Democracy: An Analysis of Dyadic Dispute, in HandBook of DefEnse Economics in a Globalized World (Todd Sandler \& Keith Hartley eds., 2007) (finding empirical support for the claim that "trading nations cooperate more and fight less"). But see John Maynard Keynes, National Self-Sufficiency, 22 STUDIES: AN IRISH Q. REV. 177, 179-80 (1933) (" $[I]$ t does not to-day seem obvious that a great concentration of national effort on the capture of foreign trade, that the penetration of a country's economic structure by the resources and the influence of foreign capitalists, and that a close dependence of our own economic life on the fluctuating economic policies of foreign countries are safeguards and assurances of international peace. It is easier, in the light of experience and foresight, to argue quite the contrary.").

295. See Chang, supra note 105. 
excess returns from foreign to domestic companies. ${ }^{296}$ This means that appropriately formulated government intervention can help a country increase its welfare at another country's expense, though such "beggar-thy-neighbor" policies often place countries in a prisoner's dilemma where intervention can be individually rational but less beneficial than a coordinated choice not to intervene. Third, even free trade at its best produces winners as well as losers, and uncompensated losses may increase inequality and thereby reduce overall welfare. ${ }^{297}$ Finally, and relatedly, free trade may undercut social norms and bargains embodied in national laws. ${ }^{298}$

Given the empirical difficulties of formulating sensible government interventions and the risk of capture of the political process by special interests, most economists continue to favor free trade at least as a "rule of thumb" in a world of government failure. ${ }^{299}$ There have been great strides in promoting multilateral legal commitments to free trade, culminating in the establishment of the World Trade Organization in 1995 , even if many barriers persist. International trade law, however, focuses primarily on cross-border restrictions to the flow of goods and services. It does little to constrain existing barriers to international investment, for which a multilateral legal framework is lacking. ${ }^{300}$

The normative debate about the merits of FDI is less robust than with respect to trade, but no less complex. FDI is defined as a cross-border equity investment in which the foreign investor exerts corporate influence over the enterprise in the host country. ${ }^{301}$ This distinguishes FDI from mere portfolio investments, which carry no influence or control rights. ${ }^{302}$ Foreign portfolio investment, which can bring both

296. For an overview of this literature, see Paul R. Krugman, Is Free Trade Passé?, 1 J. ECON. PERSP. 131 (1987).

297. See Paul R. Krugman, Trade and Wages, Reconsidered, 2008 BroOKING PAPERS ON ECON. ACTIVITY 103, 135 (suggesting that trade "has been a force for greater inequality in the United States and other developed countries"). But see Florence Jaumotte, Subir Lall \& Chris Papageorgiou, Rising Income Inequality: Technology, or Trade and Financial Globalization?, 61 IMF ECON. REV. 272, 291 (2013) (finding that trade openness reduces inequality).

298. See, e.g., Dani Rodrik, It's Time to Think for Yourself on Free Trade, ForEIGN POL'Y (Jan. 27, 2017, 7:57 AM), https://foreignpolicy.com/2017/01/27/its-time-to-think-foryourself-on-free-trade/ [https://perma.cc/YQ35-MN7D].

299. Krugman, supra note 296, at 132.

300. See Zachary Elkins, Andrew T. Guzman \& Beth A. Simmons, Competing for Capital: The Diffusion of Bilateral Investment Treaties, 1960-2000, 60 INT. ORG. 811, 812 (2006) ("[U]nlike trade and monetary relations, virtually no multilateral rules for FDI exist."). FDI is then typically regulated through bilateral investment treaties (BITs) regulating admission, treatment, expropriation, and the settlement of disputes. However, the limited scope of BITs has permitted the persistence of multiple restrictions on foreign ownership. On the reasons behind the major differences in the legal framework governing international trade and foreign investment, see Beth A. Simmons, Bargaining over BITs, Arbitrating Awards: The Regime for Protection and Promotion of International Investment, 66 WORLD POL. 12 (2014) (attributing the tighter investment regime to the greater credibility problem in this area due to more timeinconsistent preferences).

301. See Org. for Econ. Co-operation \& Dev., OECD Benchmark Definition of FOREIGN DIRECT INVESTMENT 22 (4th ed., 2008).

302. Id. 
benefits and risks to host countries, ${ }^{303}$ also has an indirect effect on corporate laws ${ }^{304}$ but is not typically as salient as FDI.

FDI comes in two forms: greenfield investments, which involve the establishment of new ventures, and mergers and acquisitions (M\&A) of existing firms. Both modes of FDI can be contentious, but takeovers of existing local firms are especially divisive ${ }^{305}$ Corporate law tools can be used to hamper both greenfield investments and M\&A, but they are, as we have seen, especially relevant with respect to the latter.

Nationalist resistance to FDI requires explanation. Unlike international trade, which assumes foreign production, FDI does not necessarily entail the outsourcing of jobs to another jurisdiction. The prevailing understanding today is that FDI substitutes for international trade in some cases but complements it in others. ${ }^{306}$ Yet even liberal-minded observers have occasionally argued that the case for FDI that displaces domestic control of major firms is weaker than the case for free trade. ${ }^{307}$

This, however, begs the question: why does foreign control of local firms appear to be so troublesome? Why does it matter to the general population that a given firm is controlled by local, rather than foreign, elites?

One simple answer is that it should not matter. Resistance to foreign control is simply the result of local elites clinging to their corporate privileges. In this view, disapproval of foreign acquisitions by the public at large lacks a rational basis. For Marx, nationalism was essentially a superstructural strategy to legitimize the interests of the bourgeoisie. ${ }^{308}$

There are, however, theoretical arguments and some empirical evidence suggesting that the nationality of corporate ownership and control can make a difference. From a functional perspective, corporate ownership matters because it confers residual control rights on shareholders to determine how the firm will behave beyond what is required by its contractual obligations and the applicable government regulations. In practice, entrenched managers and controlling shareholders retain significant discretion about the extent to which corporations will pursue financial

303. See Int'l Monetary Fund, The Liberalization and Management of Capital FLows: An Institutional View (Nov. 14, 2002), https://www.imf.org/external/np/pp/eng /2012/111412.pdf [https://perma.cc/D42B-HH2M] (discussing the efficiency benefits as well as the macroeconomic and financial stability risks associated with international capital flows). Because foreign portfolio investment is more liquid than FDI, it is also more susceptible to disruptive outflows that compromise financial stability and macroeconomic outcomes in host countries.

304. See infra notes 328-31 and accompanying text.

305. See Milhaupt, supra note 165, at 13; Nathan M. Jensen \& René Lindstädt, Globalization with Whom: Context-Dependent Foreign Direct Investment Preferences (Working Paper, 2013) (discussing a survey experiment finding that "support for new investment is substantially higher than for acquisitions of US firms").

306. See Sonal S. Pandya, Political Economy of Foreign Direct Investment: Globalized Production in the Twenty-First Century, 19 ANN. REV. POL. SCI. 455 (2016) (stating that while trade and FDI used to be substitutes, there has been a rise in FDI-trade complementarities in global production networks).

307. See supra note 131 and accompanying text.

308. See Shlomo Avineri, Marxism and Nationalism, 26 J. ConT. Hist. 637, 640 (1991). 
returns or protect stakeholder interests, as well as the strategies it will use to further its goals. ${ }^{309}$

There are different reasons why, at least in theory, domestic controllers are more likely to exercise their residual control rights for the benefit of local welfare. First, local shareholders and managers may be more likely to promote the interests of other stakeholders even if they do not benefit financially from it. This is because they derive greater nonpecuniary private benefits of control-in the form of a good reputation, influence, and recognition - from actions that benefit their communities, ranging from the preservation of local headquarters to the promotion of good working conditions and charitable contributions.

Second, and relatedly, domestic controllers share the prevailing local culture and values, and are therefore more willing and able to rely on existing social norms to promote coordination. This role will be more pronounced in economies that place greater weight on government and interfirm coordination compared to the type of market arrangements that exist in Germany and Japan. Consistent with this view, coordinated market economies appear to be far more resistant to foreign acquisitions than liberal market economies. ${ }^{310}$

Third, local managers and especially controlling shareholders are more likely to have a symbiotic relationship with the national or local political regime. Their fortune is more likely to be tied with the stability and success of the country, and they are more prone to collaborate with the state's pursuit of public policy in exchange for benefits in other dealings with the government. ${ }^{311}$ Whether viewed as sincere loyalty or quid pro quo, local controlling shareholders and managers tend to be more aligned with the state's interests, thus further promoting nationalist objectives.

To be sure, the state has other means to influence corporate action beyond relying on the spontaneous loyalty of local controllers or on informal quid pro quos. It can always mandate a given course of action through laws and regulations. Nevertheless, ownership still matters, as regulations, like contracts, cannot fully circumscribe the residual control powers associated with ownership. ${ }^{312}$ Moreover, ownership will matter more where states' regulatory powers are weak, which is the case in many jurisdictions pursuing nationalist policies. Interestingly, certain countries with relatively open takeover markets and a strong regulatory apparatus-such as the United States and especially the United Kingdom-appear to be more willing to approve foreign acquisitions by relying on contractual commitments with respect to post-closing conduct. ${ }^{313}$

309. See, e.g., Einer Elhauge, Sacrificing Corporate Profits in the Public Interest, 80 N.Y.U. L. REV. 733 (2005).

310. See Callaghan, supra note 4, at 17 (employing a "variety of capitalisms" framework to contend that "stakeholder opposition to foreign takeovers depends on how much of a threat foreign owners pose to network-based coordination").

311. The welfare implications of the symbiotic relationship between governments and local business groups remains dubious, however. See Tarun Khanna \& Yishay Yafeh, Business Groups in Emerging Markets: Paragons or Parasites?, 45 J. ECON. LiT. 331 (2007).

312. The scope of these powers varies from state to state. See Curtis J. Milhaupt, Property Rights in Firms, 84 VA. L. REV. 1145 (1998).

313. This approach is also popular in Canada, which has successfully enforced in court the 
Critics of FDI have posited that foreign- and domestic-owned firms exhibit fundamentally different behavioral patterns. Alice Amsden describes a multinational operating abroad as a "bureaucratic animal," whereas a domestic-owned firm epitomizes the "Schumpeterian ideal." ${ }^{314}$ Foreign-owned companies are less likely to innovate in host countries and tend to retain the lion's share of the high-paying managerial and scientific jobs in their home jurisdictions. ${ }^{315}$ In this view, FDI is harmful where market failures exist, since foreign firms can crowd out the more beneficial presence of local firms. ${ }^{316}$ FDI supporters, in turn, regard it as a source of much-needed investment, productivity gains, and technological spillovers. ${ }^{317}$

The existing literature on the economic consequences of FDI is inconclusive. ${ }^{318}$ There is evidence that foreign firms have higher productivity and pay higher wages than their domestic counterparts, but the effects of spillovers on local firms' productivity are unclear. ${ }^{319}$ There also appears to be no consistent relationship between FDI and host country economic growth. ${ }^{320}$ There are countries that have

undertakings given by United States Steel Corporation under the Investment Canada Act. See U.S. Steel Corp. v. Att'y Gen. of Canada, [2011] F.C.A. 176 (Can.).

314. Alice H. Amsden, Nationality of Firm Ownership in Developing Countries: Who Should 'Crowd Out' Whom in Imperfect Markets?, in Industrial PoliCy AND DeVElopment: The Political Economy of Capabilities Accumulation 410 (Mario Cimoli, Giovanni Dosi \& Joseph E. Stiglitz eds., 2009).

315. Id. at 412 (describing foreign-owned firms as "decapitated creatures"). See also PETER Evans, Dependent Development 102 (1979) (describing the absence of "pioneering" by foreign capital in Brazil).

316. See Amsden, supra note 314, at 414-15 (ascribing the superior economic performance of Asia with respect to Latin America to the lower levels of foreign control in the former).

317. See, e.g., Paul M. Romer, Idea Gaps and Object Gaps in Economic Development, 32 J. Mon. ECON. 543 (1993) (arguing that FDI can help close "idea gaps" in underdeveloped economies).

318. Robert E. Lipsey \& Fredrik Sjöholm, The Impact of Inward FDI on Host Countries: Why Such Different Answers?, in Does Foreign Direct Investment Promote Development? 23 (Theodore H. Moran, Edward Montgomery Graham \& Magnus Blomström eds., 2005) ("[On] almost every aspect of this question [of how inward FDI affects host countries] there is a wide range of empirical results in academic literature with little sign of convergence.").

319. For an influential review of the literature, see Robert Lipsey, Home and Host Country Effects of FDI (NBER Working Paper Series, Working Paper No. 9293, 2002), http://www.nber.org/papers/w9293.pdf [https://perma.cc/ABE4-KBZX]; see also Beata Smarzynska Javorcik, Does Foreign Direct Investment Increase the Productivity of Domestic Firms?: In Search of Spillovers Through Backward Linkages, 94 AM. ECON. REV. 605 (2004) (finding that, in contrast to earlier literature, there were positive productivity spillovers from FDI in Lithuania).

320. See Lipsey, supra note 319 , at 55 ("[T] he results of these studies indicate that the size of inward FDI stocks or flows, relative to GDP, is not related in any consistent way to rates of growth."); see also Maria Carkovic \& Ross Levine, Does Foreign Direct Investment Accelerate Economic Growth?, in Does Foreign DiRect InVESTMENT Promote Development? 197 (Theodore H. Moran, Edward Montgomery Graham \& Magnus Blomström eds., 2005) (“"T] influence on economic growth.”). 
prospered under both liberal and hostile FDI regimes. ${ }^{321}$ An empirical study by IMF economists has found that trade openness reduces inequality, while FDI appears to increase it. ${ }^{322}$

The existing evidence on the effects of foreign takeovers, in particular, is also mixed. A leading concern is that foreign firms will move R\&D activity to their headquarters. U.S. multinationals, for instance, use $84 \%$ of their R\&D budgets at home. ${ }^{323}$ Empirical studies have not completely dissipated this fear, especially with respect to developing countries. ${ }^{324}$ Foreign acquirers have often discontinued R\&D activities in Latin America, but in other contexts the effects have been neutral or positive. ${ }^{325}$ The record of foreign takeovers on host country productivity gains and employment outcomes is also mixed. ${ }^{326}$ Moreover, the welfare effects of foreign takeovers span well beyond the location of R\&D activities. They may not only affect domestic and foreign workers but also, through their effects on competition and governance incentives, domestic and foreign consumers and shareholders.

This unclear picture about the effects of FDI and foreign takeovers helps fuel the powerful domestic alliance favoring domestic control of industry. However, it does not explain why corporate law, rather than other regulatory instruments, is often the preferred conduit for nationalist ambitions, a topic to which I now turn.

\section{WHY CORPORATE LAW?}

The grip of nationalism on corporate law can appear puzzling at first. After all, corporate law rules are neither necessary nor sufficient to accomplish protectionist

321. Linsi, supra note 110, at 17 (citing Ireland and Singapore as an example of the former, and Japan, Korea and China as an example of the latter).

322. See Jaumotte et al., supra note 297, at 291.

323. Fear and Favour: Foreign Takeovers, supra note 130.

324. ORG. For ECON. Co-OPERATION \& DeV., InTERnAtional InVESTMENT Perspectives 2007: FreEdom OF INVESTMENT IN A CHANGING WoRLD 85 (2007) ("Empirical work on the question of the effect of foreign takeovers on existing R\&D capabilities provides no definitive answers."); see also Alice H. Amsden, Ted Tschang \& Akira Goto, Do Foreign Companies Conduct R\&D in Developing Countries? (Asia Dev. Bank Inst., Working Paper No. 14, 2001) (stating that R\&D activity in developing country rarely encompasses basic research or even applied research).

325. ORG. FOR ECON. CO-OPERATION \& Dev., supra note 324, at 85; see also UNITED NATIONS, World InVESTMENT Report 2005: Transnational CORPORATIONS AND the INTERNATIONALIZATION OF R\&D 143-46 (2005), https://unctad.org/en/Docs/wir2005_en.pdf [https://perma.cc/PGW9-9FXJ].

326. See, e.g., Martin Conyon et al., The Productivity and Wage Effects of Foreign Acquisition in the United Kingdom, 50 J. IND. ECON. 85 (2002) (finding that both domestic and foreign acquisitions are associated with higher wages and increases in productivity); John P. Geluebcke, The Impact of Foreign Takeovers: Comparative Evidence from Foreign and Domestic Acquisitions in Germany, 47 ApP. ECON. 739 (2015) ("The results for German manufacturing indicate a negative impact of foreign takeovers on employment and no productivity improvements."); Kristiina Huttunen, The Effects of Foreign Acquisition on Employment and Wages: Evidence from Finnish Establishments, 89 REV. ECON. STAT. 497 (2007) (finding that foreign acquisitions lead to higher wages but lower levels of employment of highly educated workers). 
objectives. They are not necessary because countries can, and often do, enact regulatory restrictions on foreign investments or otherwise discriminate against foreign interests. They are not sufficient because corporate law mechanisms do not guarantee the pursuit of nationalist policies when they are not in the interest of the corporation's managers and shareholders. Dual-class structures and takeover defenses can only assist national objectives if managers and controlling shareholders do not want to lose control to foreign parties. They are ineffective when corporate insiders are eager to sell at an attractive price, which can be a problem if the takeover imposes externalities on other national constituencies such as workers, communities, and the government treasury.

In view of this, most, if not all, jurisdictions continue to impose restrictions on foreign ownership of business corporations in special cases. ${ }^{327}$ These restrictionswhich apply irrespective of the eagerness of corporate insiders to sell off - can take different forms. Most countries continue to impose ownership limits that ban foreign ownership of firms in certain strategic industries beyond a certain threshold of stockholdings or voting rights.

Alternatively, or in addition, jurisdictions may subject foreign acquisitions to regulatory review and approval requirements to promote certain public policy objectives, such as ensuring the provision of public services or national security. The U.S. system of CFIUS review illustrates this approach, which has been increasingly embraced by other jurisdictions. ${ }^{328}$ Governments may also attempt to dissuade foreign acquisitions through informal means, often with significant success. ${ }^{329}$ Moreover, governments may require foreign acquirers to make special commitments to post-closing actions in the host country. ${ }^{330}$ Through post-closing undertakings or commitments, foreign acquirers and buyers rely on contractual promises to compensate for the potential loss of loyalty associated with foreign ownership. That is, contracts substitute for ownership.

By targeting only foreign owners, these restrictions appear to be more tailored to nationalist purposes and less disruptive of the governance landscape. Why, then, is

327. For an inventory of national rules discriminating against foreign investment, see Org. for Econ. Co-operation \& Dev., National Treatment for Foreign-Controlled ENTERPRISES: INCLUDING AdHERING COUNTRIES EXCEPTION TO NATIONAL TREATMENT (2013), https://www.oecd.org/daf/inv/investment-policy/national-treatment-instrument-english.pdf [https://perma.cc/A5SS-PR63].

328. See Frank Proust, Screening of Foreign Direct Investment in Strategic Sectors, EuropeAn PARLIAMENT (Oct. 20, 2019), http://www.europarl.europa.eu/legislative-train /theme-a-balanced-and-progressive-trade-policy-to-harness-globalisation/file-screening-offoreign-direct-investment-in-strategic-sectors [https://perma.cc/G2EP-UTAZ] (describing recent initiatives in the European Union).

329. I. Serdar Dinc \& Isil Erel, Economic Nationalism in Mergers and Acquisitions, $68 \mathrm{~J}$. FIN. 2471 (2013) (finding that national governments in the European Union were significantly more likely to decry foreign takeovers than domestic ones). The authors also find that such nonregulatory opposition not only hindered the deals in question but also had a chilling effect on future foreign bids in the country. Id. at 2472.

330. For the United Kingdom, see supra Section I.D. For the United States, see Milhaupt, supra note 165, at 13 (stating that Japanese firms investing in the United States in the 1980s made public commitments to maintain existing headquarters and factories to appease local fears). 
the use of corporate law for nationalist purposes so popular? One reason is that blunt foreign ownership restrictions do not differentiate between greenfield investments and foreign acquisitions, with the latter being more controversial and politically unpopular. Corporate law provisions, in turn, are more likely to disproportionately affect foreign takeovers compared to greenfield FDI. Another factor is that nationalist corporate laws do not impinge on the controllers' interest in divesting their stockholdings if they so wish and are therefore more favorable to domestic elites than coarse regulatory restrictions.

Perhaps a more fundamental reason is that regulations that overtly discriminate against foreign investors are costly from an international relations perspective. Most countries simultaneously want to prevent foreign ownership of their national champions and enable, if not encourage, acquisitions of corporate targets by their own firms abroad. However, this duplicitous position is hardly defensible, giving rise to concerns about reciprocity.

Reciprocity in takeovers matters, first, because of its intuitive and popular appeal in embodying an ideal of fairness. A recent empirical study found that reciprocity is a major determinant of public opinion with respect to foreign investments. ${ }^{331}$ Second, in the absence of reciprocity, in the long run, there will be more firms coming from countries with closed takeover markets than from countries with open ones, in ways that do not necessarily reflect efficiency advantages.

In this context, corporate law barriers operate as a form of stealth protectionism. Corporate law rules have broad applicability and are often nondiscriminatory on their face. There is major theoretical debate about the proper ends of corporate law-if to protect shareholders only or stakeholders more generally - as well as empirical uncertainty about the best means to accomplish these ends. ${ }^{332}$ Specifically, there is still considerable controversy about whether corporate law devices that entrench controlling shareholders and managers are an inefficient source of agency costs or efficient tools to protect long-term specific investments, promote entrepreneurial vision, and tackle the information and coordination problems facing outside shareholders. ${ }^{333}$ At the same time, there is broad agreement that corporate law rules can have different effects depending on the underlying context, and that different firm characteristics may require distinct legal regimes. ${ }^{334}$ This suggests that corporate

331. Adam S. Chilton, Helen V. Milner \& Dustin Tingley, Reciprocity and Public Opposition to Foreign Direct Investment, BRITISH J. POL. SCI. (2017).

332. See Stephen M. Bainbridge, The Means and Ends of Corporate Governance, $97 \mathrm{Nw.}$ U. L. REV. 547 (2003) (outlining the controversy about the ends of corporate governance, the promotion of interests of shareholders or stakeholders, and about the best means to accomplish such ends, shareholder power or managerial power); Mariana Pargendler, The Corporate Governance Obsession, 42 J. CORP. L. 359 (2016) (describing the empirical ambiguities surrounding the effects of corporate governance practices).

333. Compare, e.g., Lucian Arye Bebchuk, The Case for Increasing Shareholder Power, 118 HARV. L. REV. 833 (2005) (defending the benefits of shareholder voice and contestable control structures) with Richard Squire \& Zohar Goshen, Principal Costs: A New Theory for Corporate Law and Governance, 117 Colum. L. REV. 67 (2017) (arguing that, in view of principal costs, entrenchment devices can maximize value in some circumstances).

334. See, e.g., Squire \& Goshen, supra note 333 (criticizing "one-size-fits-all” solutions given the existence of heterogeneity among firms). 
law rules entrenching domestic control can be subject to different rationalizations that help disguise a nationalist motivation.

France, for instance, has been accused of pursuing "globalization à la carte" by supporting French firms' acquisitions of foreign targets while opposing foreign acquisitions of French companies. ${ }^{335}$ Corporate law mechanisms are an attractive tool to carry out this strategy. While France's system of tenured voting has a strong protectionist component, it can be easily justified as a means to promote long-term value. $^{336}$

The obfuscation provided by corporate law is obviously only partial. ${ }^{337}$ It is no secret that structural defenses like dual-class shares and cross-shareholdings can serve nationalist purposes and raise concerns about reciprocity. The barriers to takeovers posed by the keiretsu structure in Japan were a main policy concern in the 1980s, featuring prominently in the "Structural Impediments Initiative" aimed at lifting informal barriers to foreign investment. ${ }^{338}$ However, the initiative did little to transform Japan's economic and governance structure beyond some modest changes to competition law. The recognition of the protectionist role of corporate law also led to major policy initiatives in the European Union, though with only limited success. ${ }^{339}$

Corporate law is not the only arena where stealth protectionism plays out. There is growing suspicion, and some evidence, that governments discriminate against foreign corporations through more rigorous enforcement of national regulatory standards - behavior that is also easily explained by the political deficit of foreigners (though one cannot rule out alternative explanations). ${ }^{340}$ Commentators often voice concerns that the enforcement of European Union and Chinese antitrust laws are motivated by nationalist considerations, as are Foreign Corrupt Practices Act (FCPA) enforcement actions and hefty fines imposed by the United States on foreign financial institutions. ${ }^{341}$ For example, a study of U.S. criminal prosecutions found

335. Patrick Sabatier, Europe Faces Globalization - Part I: Wealthy Nations Practice Globalization à la Carte, by Pursuing Foreign Firms and Protecting Their Own, YALEGlobal ONLiNE (May 16, 2006), https://yaleglobal.yale.edu/content/europe-facesglobalization-part-I [https://perma.cc/ALK7-SHA6].

336. See MAZEAUd, supra notes 38.

337. The obfuscation of protectionist mechanisms is not unique to corporate law and FDI. See Daniel Y. Kono, Optimal Obfuscation: Democracy and Trade Policy Transparency, 100 ANN. Pol. SCI. REV. 369 (2006) (arguing that democracies adopt nontariff trade barriers for purposes of political obfuscation, given that voters tend to favor liberal trade policies that reduce prices and raise real incomes).

338. See Davies et. al., supra note 148 and accompanying text.

339. See supra Section I.E.

340. For instance, higher sanctions against foreign firms could be attributable to greater difficulty in monitoring and detection of wrongdoing or to nonobservable differences in the severity of the offense, or the quality of their defense and cooperation strategies.

341. See, e.g., Stephen J. Choi \& Kevin E. Davis, Foreign Affairs and Enforcement of the Foreign Corrupt Practices Act, 11 J. EMP. Legal Stud. 409 (2014) (finding that foreign companies are subject to higher sanctions for FCPA violations); John Engler, EU Has Gone Too Far Targeting US Companies, CNBC: BUS. News (Feb. 24, 2016, 1:01 PM), https://www.cnbc.com/2016/02/24/eu-has-gone-too-far-targeting-us-companiescommentary.html [https://perma.cc/E67K-CTQC]; Jean-Michel Quatrepoint, Au Nom de la 
that foreign companies received fines that were on average seven times larger and made total payments over nine times larger than comparable domestic firms. ${ }^{342}$ By potentially increasing the costs of doing business abroad, such manifestations of regulatory nationalism through differential enforcement also has indirect implications for globalization and corporate governance.

\section{IMPLICATIONS FOR THE DEVELOPMENT OF CORPORATE GOVERNANCE}

The rise of trade liberalization and the internationalization of capital markets in the last three decades has triggered a lively argument about the implications of globalization for corporate law. This debate has two camps. Proponents of the convergence thesis argue that globalization will drive corporate laws towards greater shareholder protection and standardization. ${ }^{343}$ Defenders of the persistence thesis contend that, in view of path dependence and peculiarities in local politics, existing differences in corporate governance systems around the world will endure. ${ }^{344}$ The controversy about the direction of corporate governance change does not even contemplate other possible scenarios, such as convergence towards lesser investor protection, or the emergence of newly minted differences in corporate laws.

Scholars also view the rise of foreign ownership in capital markets as an unambiguous force towards greater shareholder rights and uniformity in corporate governance practices. ${ }^{345}$ The argument, briefly, is that product market competition will put pressure on firms to lower their cost of capital. International competition for capital, in turn, will lead firms to offer more effective protections to investors. This will prompt jurisdictions to reform their laws to better protect outside shareholders, including foreign shareholders.

This reasoning, however, fails to consider the import of national politics and, specifically, the political deficit of foreign investors. Even if markets are global, corporate lawmaking remains largely territorial. While both firms and countries indeed have incentives to attract foreign investors, their incentives can rapidly change once foreigners' investment is sunk. It is well known in international affairs that foreign investors are subject to a hold-up problem. Economist Raymond Vernon famously described FDI as an "obsolescing bargain," since "almost from the moment that the signatures have dried on the document, powerful forces go to work that quickly render the agreements obsolete in the eyes of the government." ${ }^{\prime 46}$

Loi . . Américaine, LE Mondé DiPlomatiQue (Jan. 2017), https://www.mondediplomatique.fr/2017/01/QUATREPOINT/56965 [https://perma.cc/B846-QKKZ].

342. Brandon L. Garrett, Too Big to Jail: How Prosecutors Compromise with Corporations 220 (2014). But see Natalya Shnitser, A Free Pass for Foreign Firms? An Assessment of SEC and Private Enforcement Against Foreign Issuers, 119 YALE L.J. 1638, 1693 (2009) (finding that the SEC was less likely to bring enforcement actions against foreign issuers compared to domestic issuers).

343. See, e.g., Hansmann \& Kraakman, supra note 2.

344. See, e.g., Bebchuk \& Roe, supra note 13.

345. See Hansmann \& Kraakman, supra note 2; Fox, supra note 12.

346. Raymond Vernon, Sovereignty at Bay: The Multinational Spread of U.S. ENTERPRISES 46-47 (1971). On the government incentives to expropriate foreign investors, see also David W. Leebron, A Game Theoretic Approach to the Regulation of Foreign Direct 
The political pull to expropriate or otherwise abuse foreign investors is familiar. ${ }^{347}$ This very prospect has prompted a complex network of bilateral investment treaties (BITs) to protect foreign investors from subsequent regulatory changes in the host country that diminish the value of their investment. ${ }^{348}$ In a similar vein, economists have recently argued that financial globalization increases governments' incentive to default on sovereign debt because creditors are more likely to be foreign. ${ }^{349}$

This view has clear, though thus far neglected, implications for the evolution of corporate governance. It suggests that, contrary to existing predictions, the rise of foreign investors will not inexorably lead to greater investor protection. Instead, when local capital markets become populated by foreign investors, the political economy may come to favor corporate arrangements that privilege domestic parties like managers, controlling shareholders, and workers, to the detriment of foreign investors. In this dynamic view of globalization, the result may be neither convergence nor persistence in corporate governance, but backlash against (foreign) shareholder-oriented practices.

We are already reaching this stage in numerous jurisdictions. As depicted in Table 1 below, foreign ownership has increased dramatically in recent years, though not to the same extent in all countries. From the early 1990s to the 2010s, the participation of foreign investors in local stock markets increased from approximately $5 \%$ to $18 \%$ in the United States, from $16 \%$ to nearly $60 \%$ in the United Kingdom, from $9 \%$ to $56 \%$ in Germany, from $22 \%$ to $47 \%$ in France, from $8 \%$ to $27 \%$ in Japan, and from $9 \%$ to $25 \%$ in Brazil. Consistent with the backlash hypothesis, legal and popular resistance to foreign takeovers have likewise increased. Commentators have described the recent rise of economic patriotism in France as "odd and incoherent" given France's status as the E.U. leader as a recipient of FDI. ${ }^{350}$ However, the political deficit of foreigners and the hold-up problem facing foreign investors help explain how rising levels of FDI and foreign portfolio investment can instead fuel a nationalist response.

Investment and the Multinational Corporation, 60 U. CIN. L. REV. 305, 313, 325 (1991).

347. See Amy Chua, The Privatization-Nationalization Cycle: The Link Between Markets and Ethnicity in Developing Countries, 95 Colum. L. REv. 223, 226 (1995) (examining the cyclicality of economic liberalization and nationalistic backlash against both foreign investors and local ethnic minorities, which she terms "foreigners within").

348. See supra note 300 and accompanying text.

349. Fernando Bromer \& Jaume Ventura, Rethinking the Effects of Financial Globalization, 131 QUART. J. ECON. 1497 (2016).

350. Sabatier, supra note 335. 
Table 1: Foreign Ownership as a Percentage of Stock Market Capitalization ${ }^{351}$

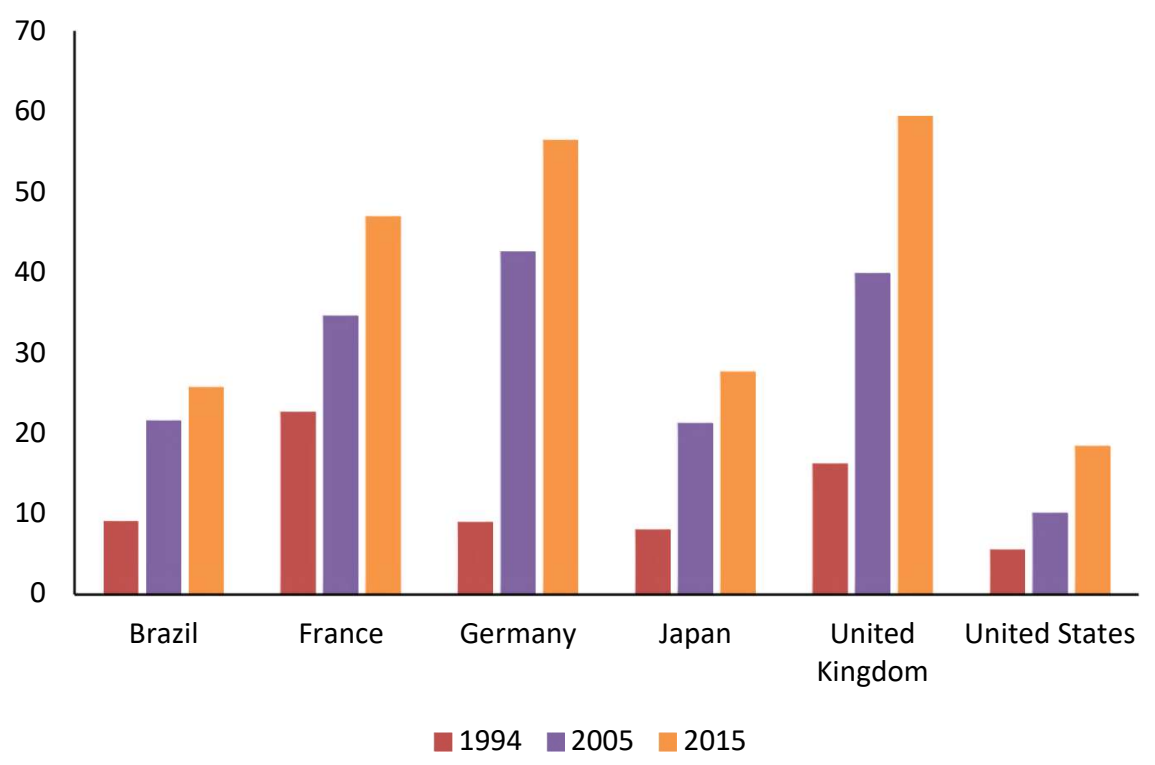

There are other factors that fuel the tension between the rise of foreign ownership and continued market integration and strong shareholder rights. In its controversial decision in Citizens United v. FEC, ${ }^{352}$ the U.S. Supreme Court recognized the First Amendment rights of corporations to make political contributions. However, as the dissenting opinion by Justice Stevens and President Obama's critique of the decision recognized, the ruling created an avenue for foreign interference in U.S. elections. ${ }^{353}$ This undesirable outcome is becoming increasingly viable given the rising levels of foreign ownership of U.S. public firms. ${ }^{354}$ Yet, given the extension of First Amendment rights to business corporations, there is no easy way of avoiding this problem without discriminating against foreign-owned or controlled corporations and, in turn, restricting foreign ownership. ${ }^{355}$

351. Data for 2005 and 2015 come from World Bank (http://data.imf.org/regular.aspx?key=60587815) and IMF indicators (http://data.imf.org /regular.aspx?key=60587815) indicators. Data for 1994 come from different sources: U.S. Department of Treasury (United States); Office for National Statistics (United Kingdom); Tokyo Stock Exchange Shareownership Survey (Japan); Gourevitch \& SHINN, supra note 11, at 105 (France); Banco Central do Brasil and OECD (Brazil).

352. 558 U.S. 310 (2010).

353. Id. at 465 (Stevens, J., concurring in part and dissenting in part) ("Unlike voters in U.S. elections, corporations may be foreign controlled."); see also President Barack Obama, State of the Union Address (Jan. 27, 2010) ("[L]ast week, the Supreme Court reversed a century of law that I believe will open the floodgates for special interests including foreign corporations to spend without limit in our elections.").

354. See Table 1.

355. For a discussion of possible different responses to this concern, see Reuven S. AviYonah, Citizens United and the Corporate Form, 2010 Wis. L. REV. 999 (2010). 
Fear of foreign investors is exacerbated when they have links to foreign governments. Concerns about sovereign wealth funds have led prominent corporate law scholars to propose their disenfranchisement (through, for example, the temporary suspension of voting rights held by SWFs) as a "minimalist" response to the potential "loss of sovereignty and distortion of markets." ${ }^{356}$ However, potential political motives are not limited to state-controlled entities; individuals as well as politically-connected foreign private firms may exhibit them as well. ${ }^{357}$ Consequently, this type of response risks changing the fabric of corporate law and governance.

The existing regulatory framework is ill-equipped to deal with this problem. As previously mentioned, there is no multilateral framework applicable to foreign investments. The international coverage of BITs is broad but not universal. Most importantly, the application of BITs to changes in corporate laws is still untested and unclear. Corporate law changes tend to be general in scope and do not overtly discriminate against foreign investors. It is unlikely that most corporate law changes could qualify as an indirect expropriation that violates treaty guarantees of "fair and equitable treatment." A related hurdle concerns proof of harm and causation. The multipurpose character of corporate law rules, as well as the existing uncertainty about the effects of different legal rules, makes it difficult to demonstrate and much less quantify the harm suffered by foreign investors from corporate law reforms.

While the analysis in this Article focuses on the common influence of nationalism in the jurisdictions examined, it also reveals variation in their prevalence over time and place. Nationalist corporate laws have been less conspicuous in the United Kingdom and in the United States. Early industrialization, a robust financial sector, high levels of stock ownership by households, corporate lawmaking by courts and self-regulatory bodies, and the complementary institutions of a liberal market economy (such as an adaptable workforce and the use of market for intersectoral coordination) all serve as a relative buffer against nationalist corporate policies. By contrast, late industrialization, underdeveloped capital markets, fear of domination by a foreign superpower, and corporate lawmaking by legislatures facilitate the nationalist grip on corporate laws. Yet even the select set of "market-dominant small jurisdictions"- which command offshore finance by catering to the interests of foreign investors as a state strategy ${ }^{358}$ - have their share of nationalist policies in certain areas, as illustrated by the protectionist corporate laws of Switzerland and the prevalence of state-owned enterprises in Singapore.

356. Ronald J. Gilson \& Curtis J. Milhaupt, Sovereign Wealth Funds and Corporate Governance: A Minimalist Response to the New Mercantilism, 60 StAn. L. REV. 1345, 1369 (2008). But see Richard Epstein \& Amanda Rose, The Regulation of Sovereign Wealth Funds: The Virtues of Going Slow, 76 U. CHI. L. REV. 111, 130 (2009) (attributing hostility to SWFs to "old-fashioned protectionism or, more generously, residual concern about the possible national security threats posed by foreign sovereign investment in the United States").

357. For the argument that ownership is not dispositive of government influence in the Chinese context, see Curtis J. Milhaupt \& Wentong Zheng, Beyond Ownership: State Capitalism and the Chinese Firm, 103 GEO. L.J. 665 (2015).

358. See Christopher M. Bruner, Re-Imagining Offshore Finance: MarketDominant Small Jurisdictions in a Globalizing FinANCial World (2016). 
If the goal is to restrict the encroachment of nationalist objectives on corporate law and governance, a multilateral initiative for corporate law harmonization appears to be necessary but is not without challenges. It would inevitably entail the political trilemma of the world economy identified by Dani Rodrik, which makes it difficult to simultaneously satisfy the ideals of deep economic integration, nation-state sovereignty, and democratic politics. ${ }^{359}$ In the corporate law context, in particular, the project of promoting deep economic integration through the elimination of protectionist barriers faces distinct shortcomings.

First, regulatory harmonization has significant disadvantages when firms and jurisdictions are heterogeneous and there is uncertainty about the optimal legal regime, as is the case in this area. ${ }^{360}$ Second, the harmonization project faces significant practical opposition since the same political coalition that favors nationalist corporate laws will oppose the liberalization of the legal regime at the international level. The political hurdles can be significant, as illustrated by the European Union's disappointing experience with the Takeover Directive.

A third and perhaps more fundamental challenge is conceptual. Legal instruments like poison pills and multivoting shares, while helpful in deterring foreign takeovers, can potentially serve other defensible objectives, such as increasing long-term investments. At this point, it is unclear that the drawbacks of nationalist corporate governance are sufficiently important to limit the availability of governance structures that reduce the contestability of control.

More importantly, it is difficult to expunge the pursuit of nationalist objectives from corporate governance without altering the fabric of corporate law and modern capitalism. Even if there is sufficient consensus that the benefits of market integration justify a ban on takeover defenses such as poison pills and dual-class structures - as E.U. experts concluded in the early $2000 \mathrm{~s}^{361}$ - these measures do not guarantee the contestability of control in all contexts. As argued by Sweden and other jurisdictions at the time, various countries retain entrenched domestic control through majority ownership by private parties and the state, which remains unaltered by board neutrality and the breakthrough rule.

One possible response would be to impose a modified breakthrough rule that imposes one vote per shareholder in the context of a tender offer, as was discussed in the E.U. context. ${ }^{362}$ This measure, however, is quite drastic in deviating from the general principle of proportionality between cash flow and voting rights, which is a core tenet of modern corporate law and for good reason. Moreover, even a modified breakthrough rule would not capture companies that are wholly owned, as many SOEs are.

It is presently unclear whether the European Union's fight against takeover restrictions has had a beneficial effect on market integration and corporate governance. The ECJ's rejection of golden shares as an unreasonable restriction to the free movement of capital may have had the unintended consequences of

359. DAni Rodrik, The Globalization Paradox (2011).

360. See Gilson et al., supra note 231, at 480 (describing the different rationales for maintaining dual or multiple regulatory regimes).

361. See supra notes 143-144 and accompanying text.

362. Marco Becht, Reciprocity in Takeovers (European Corp. Governance Inst., Working Paper No. 14/2003, 2013). 
encouraging states to intervene by acquiring or maintaining stockholdings in corporations. This stronger form of intervention through state ownership not only allows for potentially greater interference on firm-level decisions but also furthers the nationalist-inspired reforms of general corporate laws, as in France's stronger embrace of double-voting rights. ${ }^{363}$

Interestingly, the recent Japan-European Union Partnership Agreement signed in July 2018, which aims at promoting both free trade and investment, boasts its unique character as the first international agreement containing provisions on corporate governance. ${ }^{364}$ The agreement covers areas such as shareholder rights, access to key information on the control or management of the company, board accountability and independence, and fair and transparent conditions for takeovers. ${ }^{365}$ It seems that the inclusion of such a corporate governance chapter seeks to mitigate precisely the problems identified in this Article: the use of corporate law as stealth protectionism ${ }^{366}$ and the need to protect foreign investors against reversals of existing levels of shareholder protection. ${ }^{367}$ While it is not clear that the generic provisions included in the Partnership Agreement are sufficient to accomplish these goals, this is certainly a notable development. Mitigating the grip of nationalism on corporate law is challenging, but possibly worthwhile, and certainly deserving of future consideration.

\section{CONCLUSION}

The grip of nationalism on corporate law shows how governance structures matter in ways that far surpass the agency cost considerations that dominate the literature. Even conventional stakeholder theories, which incorporate the interests of workers, consumers, and communities, may still be too narrow in focus. Corporate law serves as an instrument to maintain autarky or promote economic integration, choices that bear major economic repercussions. Continued international convergence towards investor protection is not certain, nor is stasis the only alternative; instead, backlash is a serious possibility.

The bond between nationalism and corporate law has proven to be surprisingly durable. In the absence of a large-scale multilateral effort, the most serious threat to its persistence comes from the possible effacement of nationalism itself. Despite the

363. See supra Section I.A.

364. European Comm'n, The ECONOMic IMPACt of the EU - JAPAN ECONOMiC PARTNERShip AgreEMENT (EPA) 32 (2018). For a discussion of the Japan-European Union Partnership Agreement, see Ram Sachs, The International Law of Corporate Governance, 32 PACE INT'L L. REV. 57 (2019) (highlighting the implicit and explicit provisions affecting corporate governance in international trade and investment agreements).

365. EuROPEAN COMM'N, supra note 364, at 32.

366. Id. ("Such guarantees are valuable to investors because they ensure that, even if from a regulatory point of view a sector is open for establishment, there are no hidden 'behind-theborder' obstacles governing the way in which an enterprise is managed or controlled, which would de facto limit the access of potential investors or the rights of existing shareholders.").

367. Id. ("[T]he agreement guarantees stability and predictability with regard to the corporate governance framework, setting a high level of ambition in this respect, which any future developments or changes must comply with.”). 
recent resentment against globalization, nationalist sentiment is arguably less pronounced than it was in previous historical periods. ${ }^{368}$ Emerging technological advances are likely to reduce the import of territorial boundaries that serve as the very foundation of nation-states.

Moreover, a central premise of control nationalism is that controlling elites have strong ties of loyalty and shared interests with their home states. However, the rise of a global elite with a strong cosmopolitan orientation - whose members have more in common with one another than with their home-country neighbors-raises questions about the continued plausibility of this assumption. ${ }^{369}$ Lashkimi Mittal, the Indian founder and CEO of ArcelorMittal, lives in London, and so do many Russian oligarchs. ${ }^{370}$ Peter Thiel, a prominent Silicon Valley investor who was born in Germany, secured New Zealand citizenship after spending only 12 days in that country. ${ }^{371}$

This cosmopolitan orientation of the emerging global elite is likely to affect not only places of residence but also corporate decisions. The surge in tax-driven changes of corporate domicile through "inversion" transactions - which imply a significant loss of tax revenue to the original home state - shows that the link between nationstates and corporations are becoming increasingly tenuous. ${ }^{372}$ Even charitable contributions by today's cosmopolitan elite are less focused on the donors' country of origin. ${ }^{373}$

Even if nation-states and nationalism may lose importance in the future, we are clearly not there yet. The prognoses about the irrelevance of corporate nationality in the 1990s turned out to be premature. ${ }^{374}$ So long as nationalism persists, its hold on corporate law and governance structures is likely to endure. This appreciation should inaugurate a new research agenda that incorporates the broader geopolitical and

368. Harari \& Anderson, supra note 1.

369. See generally Chrystia Freeland, Plutocrats: The Rise of the New Global SuPER-Rich AND THE FALl OF EVERYONE ELSE (2012).

370. Id.

371. Eleanor Ainge Roy, New Zealand Gave Peter Thiel Citizenship After He Spent Just 12 Days There, GuARDian (June 29, 2017, 3:03 PM), https://www.theguardian.com/world /2017/jun/29/new-zealand-gave-peter-thiel-citizenship-after-spending-just-12-days-there [https://perma.cc/S8NH-N86S].

372. See, e.g., Leo E. Strine, Jr., Corporate Power Is Corporate Purpose II: An Encouragement for Future Consideration from Professors Johnson and Millon, 74 WASH. \& LEE L. REV. 1165 (2017). While the debate about corporate inversions is usually framed in terms of tax consequences, another concern is that the cross-border merger now required to bring about an inversion may also lead to a change in headquarters. See Collen Walsh, Getting a Handle on Inversion: A Q\&A with Mihir Desai, HAR. L. TODAY, (Aug. 15, 2014), https://today.law.harvard.edu/harvard-gazette-mihir-desai-getting-handle-inversion/ [https://perma.cc/SQZ5-6QRL].

373. FREELAND, supra note 369.

374. Robert Reich, The Work of Nations: Preparing Ourselves for 21st Century CAPITALISM 136 (1991) (declaring the "coming irrelevance of corporate nationality"). But see Laura Tyson, They Are Not Us: Why American Ownership Still Matters, AM. Prospect (Dec. 5, 2000), https://prospect.org/world/us-american-ownership-still-matters/ [https://perma.cc /MT5L-N9MC] (arguing that Reich's prognosis is, "at best, premature," as "[t]he economic fate of nations is still tied closely to the success of their domestically based corporations"). 
developmental consequences of corporate law and its broader impact on the economy and society. 